\title{
In Mitigation of the Penalty of Death: Lockett $v$. Ohio and the Capital Defendant's Right to Consideration of Mitigating Circumstances
}

\author{
Randy Hertz† and Robert Weisberg $\ddagger$
}

In five cases decided on the same day in $1976,{ }^{1}$ the United States Supreme Court held that the Constitution requires the sentencing judge or jury in a capital case to consider evidence offered by the defendant to mitigate his sentence. Two years later, in Lockett $v$. Ohio, ${ }^{2}$ the Court struck down the Ohio death penalty statute because it unconstitutionally restricted the capital defendant's right to sentencer consideration of mitigating circumstances concerning his character, record, and offense. At first blush, the Lockett decision appears to be little more than a simple extension of the 1976 Cases, ensuring that states do not use restrictive statutory lists of initigating circumstances to bar the capital sentencing authority from considering any proffered mitigating factors or evidence. With rare exception, the lower courts ${ }^{3}$ and commenta-

$\dagger$ B.A. 1976, Carleton College; J.D. 1979, Stanford Law School; member, District of Columbia bar.

$\ddagger$ B.A. 1966, City College of New York; Ph.D. 1971, Harvard University; J.D. 1979, Stanford Law School; member, California bar.

1. The terms "1976 Death Penalty Cases" and "1976 Cases" will be used in this Article to refer collectively to the five capital puuishment decisions handed down by the Supreme Court on July 2, 1976: Roberts v. Louisiana, 428 U.S. 325 (1976); Woodson v. North Carolina, 428 U.S. 280 (1976); Jurek v. Texas, 428 U.S. 262 (1976); Proffitt v. Florida, 428 U.S. 242 (1976); and Gregg v. Georgia, 428 U.S. 153 (1976).

2. 438 U.S. 586 (1978).

3. In determinimg whether a state death penalty statute complies with Lockett, lower courts routinely have considcred only this requirement and have approved the statute as long as the roster of mitigatimg circumstances is nonexclusive. See, e.g., Jacobs v. State, 361 So. 2d 640, 65253 (Ala. 1978) (on rehearing); State v. White, 395 A.2d 1082, 1087-88 (Del. 1978); State v. Coleman, 605 P.2d 1000, 1016-17 (Mont. 1979), cert. denied, 100 S. Ct. 2952 (1980). The lower courts almost uniformly have rejected defendants' claims that Lockett establishes additional requirements for sentencer cousideration of mitigating circumstances. See, e.g., Collier v. State, 244 Ga. 553, 568-69, 261 S.E.2d 364, 376-77 (1979) (rejecting claim that Lockett requires specific mention of proffered mitigating circumstances in jury instructions); Adams v. State, 577 S.W.2d 717, 729. 30 (Tex. Crim. App. 1979), rev'd on other grounds, 100 S. Ct. 2521 (1980) (rejecting claim that Lockett requires that sentencer be permitted to consider each mitigating circumstance as a reason in and of itself for imposing a noncapital sentence). For further discussion of this lower court case 
tors ${ }^{4}$ have treated it as no more than that. Careful study of Lockett reveals, however, that the decision applies more broadly than has been recognized and delineates the capital defendant's eighth amendment rights in ways not yet appreciated. The changes that Lockett works in eighth amendment law are subtle, but may dramatically affect the nature and scope of capital sentencmg hearings. In fact, of the three state death penalty statutes upheld in the 1976 Cases, none would pass constitutional inuster when considered in liglit of Lockett. ${ }^{5}$ This Article examines Lockett and its significance for the right of capital defendants to sentencer consideration of mitigating circumstances.

Part I of this Article reviews the Lockett decision against the background of the Court's major death penalty decisions. Part II considers the broader implications of the Lockett decision for the capital defendant's right to present mitigatimg circumstances of character, record, and offense by testing these implications against the death penalty laws in Georgia and Texas-statutes that the Court upheld in 1976. Part III considers the problems of applying Lockett to other state statutes by examining the Florida deatli penalty statute, the third statute that the

law, see notes 66-77, 129, and accompanying text infra. For a unique example of a broad reading of Lockett by a lower court, see Chenault v. Stynchcombe, 581 F.2d 444, 447-48 (5th Cir. 1978) (Wisdoin, J.) (recognizing that Lockett requires specific refereuce to proffered mitigating circumstances in jury instructions).

4. See, e.g., Comment, Individualized Sentencing Determination, 12 AkroN L. Rev. 360 (1978); Comment, The Role of Mitigating Circumstances in Considering the Death Penalty, 53 TuL. L. REv. 608 (1979) (noting, however, unportant ambiguities in Lockett). Oue Comment found broader significance in Lockett only for the issues of a defendant's right to a bifureated trial with separate hearings for guilt and sentencing and right to senteucing by a jury. The Supreme Court, 1977 Term, 92 HARv. L. REv. 57, 103 n.38 (1978). Some commentators have perceived in Lockett the concealed adoption of a stricter standard of judicial review of capital legislation, but have not identified any serious changes that it makes in the substantive doctrines established in the 1976 Death Penalty Cases. Manheim, The Capital Punishment Cases: A Criticism of Judicial Method, 12 LoY. L.A. L. REv. 85, 126-31, 134 (1978); Commeut, Right of a Defendant to Have Any Relevant Aspects of His Character and Circumstances of Offense Used as Factors Mitigating a Death Sentence, 25 WAYNE ST. L. REv. 1147 (1979).

5. In describing the three statutes sustained in the 1976 decisions, the Lockett Court noted that "[n]one of the statutes we sustained . . . clearly operated at that time to prevent the sentencer froin considering any aspect of the defendant's cluaracter and record or any circumstances of his offense as an independently untigating factor." 438 U.S. at 607 . Although one lower court has interpreted this passage from the Lockett opimion as expressly holding that these three statutes comply with all Lockett requireinents, Spinkellink v. Wamwright, 578 F.2d 582, 620-21 (5th Cir. 1978), cert. denied, 440 U.S. 976 (1979), the Lockett Court could not and did not decide the constitutionality of statutes that were not before it. Rather, the Court was commenting that any constitutional deficiencies in the three statutes had not been "clearly" apparent in 1976 and that the language of each of the statutes appears to provide for sentencer consideration of any and all mitigating circumstances. Lockett v. Ohio, 438 U.S. at 606-07. In the following discussion, we will examine closely the language of the three statutes and the case law imterpreting them to demonstrate that this imitial impression of the statutes is incorrect. All three unconstitutionally restrict the capital defeudant's eighth amendmeut right to senteucer cousideration of mitigating circumstances. 
Court upheld in 1976 and a statute that, but for soine questionable judicial reconstruction, should have been invalidated under Lockett. The Article concludes by proposing a general inethod for applying the requirements of Lockett and by exploring other changes in capital sentencing procedures which, although not set forth in the Lockett opinion, nevertheless follow logically from the principles announced in the case.

\section{I \\ LOCKETT: BACKGROUND AND HOLDING \\ A. Capital Defendants' Pre-Lockett Right to Present Mitigating Circumstances}

The foundation of modern death penalty law is the Supreme Court's 1972 decision in Furman v. Georgia. ${ }^{6}$ In a terse per curiam opinion, a five-Justice majority reversed several death sentences imposed under the Georgia and Texas death penalty statutes on the ground that the sentences were cruel and imusual punishments in violation of the eighth amendment. The five Justices in the majority all filed separate opinions, the prominent themes of which were that sentencing authorities exercismg unbridled discretion in capital cases acted capriciously in selecting defendants for execution and were prone to discrimination against minority defendants. ${ }^{7}$ The plethora of opimons prevented Furman froin clearly establishing constitutional requirements for capital sentencing, but the immediate effect of Furman was far-reaching: The decision invalidated all capital sentencing schenies then in effect in the United States. ${ }^{8}$

In the wake of Furman, the legislatures of thirty-five states revised

6. 408 U.S. 238 (1972).

7. Furman v. Georgia, 408 U.S. at 240-57 (Douglas, J., concurring) (discretionary sentencing procedures permit discriminatory sentences); $i d$. at 291-300 (Brennan, J., concurring) (statutes permit capricious senteucing); id. at 309-10 (Stewart, J., concurring) (statutes permit randoun and capricious inposition of death penalty); $i d$. at 311-14 (White, J., concurring) (infrequent imposition of death penalty unakes it unusual and pointless punishment); id. at 364-66 (Marshall, J., concurring) (death peualty discriminates against minority group defendants). Justices Brennan and Marshall also concluded that the death penalty was per se unconstitutional. Id. at 305-06 (Brennan, J., concurring); id. at 370-71 (Marshall, J., concurring). For a full analysis of Furman, see England, Capital Punishment in the Light of Constitutional Evolution: An Analysis of Distinctions Between Furman and Gregg, 52 Notre DAME LAw. 596, 596-600 (1977); The Supreme Court, 1971 Term, 86 HARv. L. REv. 52, 76-85 (1972).

8. Each of these scheines involved the type of absolute sentencer discretion condemned in Furman. See Lockett v. Ohio, 438 U.S. at 597-99; M. MelTSNer, Cruel and Unusual: The Supreme Court and Capital Punishment 292-93, 299-300 (1973). Subsequently, the various state supreme courts performed the task of actually invahdating their respective death penalty statutes. E.g., Hubbard v. State, 290 Ala. 118, 120, 274 So. 2d 298, 301 (1973); State v. Schmid, 109 Ariz. 349, 356, 509 P.2d 619, 626 (1973); State v. Gibson, 259 S.C. 459, 192 S.E.2d 720 (1972); State v. Baker, 81 Wash. 2d 281, 501 P.2d 284 (1972). 
their death penalty statutes or enacted new ones, ${ }^{9}$ attempting to construct capital sentencing procedures that imcorporated the criteria suggested in the concurring opinions in Furman. ${ }^{10}$ The disunity among the Furman opinions, however, resulted in wide variations among the new state statutes. ${ }^{11}$ The statutes generally took one of two forms: (1) a statute iniposing a mandatory death sentence for all defendants convicted of any of several enumerated capital crimes; or (2) a guided discretion statute giving the sentencing judge or jury discretion in imposing death, but guiding the sentencer's decision through express standards-normally imvolving lists of, or questions about, aggravating and 1mitigatimg factors. ${ }^{12}$

In the 1976 Death Penalty Cases, the Supreme Court considered the constitutionality of both types of statutes. The Court upheld the guided discretion statutes enacted by Georgia, ${ }^{13}$ Florida, ${ }^{14}$ and Texas, ${ }^{15}$ but struck down the mandatory death penalty statutes of North Carolina ${ }^{16}$ and Louisiana. ${ }^{17}$ These decisions, although consisting entirely of plurality opinions, concurrences, and dissents, ${ }^{18}$ established an essentially coherent theory of the requirements of the eighth amendment for a constitutional death penalty scheme. Addressing the petitioners' contention that the death penalty is per se cruel and unusual, the plurality established and applied two eighth amendment criteria: A punishment avoids the prohibition of the eighth amendment if it accords both with "evolving standards of decency" as reflected in contemporary public attitudes, ${ }^{19}$ and with the moral concept of the "dignity of man" that hes at the foundation of the eighth amendment. ${ }^{20}$ The plurality

9. England, supra note 7, at 601-02.

10. Lockett v. Ohio, 438 U.S. at 599-600.

11. Id. For detailed discussion of the various statutory schemes, see Note, Discretion and the Constitutionality of the New Death Penalty Statutes, 87 HARV. L. REv. 1690, 1699-1712 (1974); Note, Furman 10 Gregg, The Judicial and Legislative History, 22 How. L.J. 53, 86-91 (1979).

12. Lockett v. Ohio, 438 U.S. at 599-600.

13. Gregg v. Georgia, 428 U.S. 153 (1976).

14. Proffitt v. Florida, 428 U.S. 242 (1976).

15. Jurek v. Texas, 428 U.S. 262 (1976).

16. Woodson v. North Carolina, 428 U.S. 280 (1976).

17. Roberts v. Louisiana, 428 U.S. 325 (1976).

18. A plurality consisting of Justices Stewart, Powell, and Stevens formed the core of the shifting majority that upheld the Georgia, Florida, and Texas statutes and invalidated the North Carolina and Louisiana statutes. Justices White, Blackmun, and Rehnquist and Chief Justice Burger concluded that all five of the death penalty statutes were constitutional and provided a majority for approving the Georgia, Florida, and Texas statutes. Justices Brennan and Marshall concluded that capital punishment is per se unconstitutional and formed the remaining part of the majority for striking down the North Carolina and Louisiana statutes. For further discussion of the various opinions in these cases, see The Supreme Court, 1975 Term, 90 HARv. L. REv. 58, 6376 (1976).

19. Gregg v. Georgia, 428 U.S. at 173 (quoting Trop v. Dulles, 356 U.S. 86, 101 (1958) (plurality opinion)).

20. Gregg v. Georgia, 428 U.S. at 173 (quoting Trop v. Dulles, 356 U.S. at 100). See Coker 
concluded that capital punishment met the first test because public attitudes, as measured by such objective evidence as recent legislative enactments and jury verdicts, demonstrated that contemporary standards of decency were consistent with the sanction of death in appropriate cases. ${ }^{21}$ The plurality also found that the death penalty did not categorically offend the eighth amendment concept of the "dignity of man," both because it could further the legitimate penological goals of deterrence and retribution ${ }^{22}$ and because it was not disproportionate to the murder offenses for which it was generally imposed. ${ }^{23}$

The 1976 Death Penalty Cases approved those capital sentencing procedures im which the sentencing judge or jury measures aggravating circumstances against mitigating circumstances to determine whether death is an appropriate pumshment for the individual defendant. The plurality explained that such a procedure cures the arbitrariness con-

v. Georgia, 433 U.S. 584, 592 (1977) (explaining the analysis in the 1976 Death Penalty Cases). For an extensive discussion of the eighth anendment analysis applied in the 1976 decisions, see Liebınan \& Shepard, Guiding Capital Sentencing Discretion Beyond the "Boiler Plate": Mental Disorder as a Mitigating Factor, 66 GEO. L.J. 757, 762-77 (1978).

21. Gregg v. Georgia, 428 U.S. at $173,176-82$.

22. Id. at 183-87. The eighth amendinent requires a legitimate penological purpose for a punishment to ensure that the penalty is not a gratuitous and wanton infliction of pain. Id. at 173 , 182-83. In discussing the penological justifications for the death penalty, the Court acknowledged that the evidence of any deterrent value of capital punishment is at best inconclusive, but deferred to the apparent legislative judgment that the use of the death penaity will deter future crimes. Id. at 184-86. Two other penological justifications for criminal penalties, incapacitation of the offender and rehabihtation, played no part in the Court's analysis. The plurality noted that protection of society through imcapacitation of dangerous offenders is frequently advanced as a justification for the death penalty, but did not rely on this justification in any manner. $I d$. at 183 n.28. As Mr. Justice Marshall poimted out, mcapacitation provides hittle if any support for the use of capital punishment, since life imprisonment without the possibility of parole is equally effective in protecting society from the particular offender. Id. at $236 \mathrm{n.14}$ (Marslall, J., dissenting); accord, Commonwealth v. O'Neal, 369 Mass. 242, 258-59, 339 N.E.2d 676, 685 (1975) (Tauro, C.J., concurring); The Supreme Court, 1975 Term, 90 HARv. L. REv. at 72. The penological objective of rehabilitation is of course inapplicable to any discussion of the final and irrevocable punishment of death. Furman v. Georgia, 408 U.S. at 206 (Stewart, J., concurring).

23. Under the proportionality component of the eighth amendment human digmity principle, a punishment is unconstitutionally excessive if it is invariably disproportionate to the offense for which it is imposed. Coker v. Georgia, 433 U.S. 584, 591-92 (1977). Although concluding that capital punishment is not invariably disproportionate to capital murder offenses, the Court explained that a defendant may still claim that death is invariably disproportionate to a particular type of capital offense. Gregg v. Georgia, 428 U.S. at 187 \& n.35; see, e.g., Coker v. Georgia, 433 U.S. 584 (1977) (holding that capital punishment is unconstitutionally disproportionate to the offense of rape). See also Lockett v. Ohio, 438 U.S. at 624-28 (White, J., concurring and dissenting) (concluding that the death penalty is invariably excessive for murderers who did not intend to cause the death of the victim); Woodson v. North Carolina, 428 U.S. 280, 305 n.40 (1976) (reserving the question of whether the punishment of death is invariably disproportionate for murderers acting under duress and not fully participating in the crime). For further discussion of the apphcation of the proportionality primciple to capital cases, see Radim, The Jurisprudence of Death: Evolving Standards for the Cruel and Unusual Punishments Clause, 126 U. PA. L. REV. 989 (1978). On the apphication of the proportionality principle to noncapital cases, see Rummel v. Estelle, 100 S. Ct. 1133, 1138-40 (1980). 
demned in Furman by providing standards to guide the sentencing authority in choosing the appropriate sentence. ${ }^{24}$

The 1976 Death Penalty Cases thus established that sentencer consideration of "mitigatimg circumstances" 25 is a constitutionally mandated part of any capital sentencing procedure. The plurality explained that the severity and irrevocability of a death sentence require a reliable determination of the appropriateness of such a sentence. ${ }^{26}$ The Constitution requires an individualized sentencing determination -with sentencer consideration of both the reasons for and the reasons agamst imposing the death penalty-as a means of achieving reliability in capital sentencing. ${ }^{27}$ Indeed, the primary constitutional deficiency of the mandatory death penalty statutes was that they precluded sentencer consideration of mitigating circumstances. ${ }^{28}$

24. Jurek v. Texas, 428 U.S. at 270-74; Proffitt v. Florida, 428 U.S. at 251-53; Gregg v. Georgia, 428 U.S. at 196-98. In upholding the Georgia, Florida, and Texas statutory provisions for weighing aggravating and mitigating circumstances and imposing punishment, the Court approved the statutes on their face and did not address their constitutionality as construed or aetually applied by the lower courts. See Godfrey v. Georgia, 100 S. Ct. 1759, 1762 (1980) (explaining that the Georgia statute was sustained as constitutional "on its face" in 1976, and that the Godfrey case presented the very different question of the constitutionality of the statute as construed and apphied); Jurek v. Texas, 428 U.S. at 270-74; Proffitt v. Florida, 428 U.S. at 251 (procedures constitutional "on their face"); Gregg v. Georgia, 428 U.S. at 198 ("On their face these procedures seen to satisfy the concerns of Furman.").

25. A "mitigating circumstance," sometimes called a "Initigating factor," Lockett v. Ohio, 438 U.S. at 606-08, or "mitigating fact," Roberts v. Louisiana, 431 U.S. 633, 637 (1977) (per curiam); Gregg v. Georgia, 428 U.S. at 197, is an attribute of the defendant's character, record, or offense that by its very nature "mitigate[s] agamst imposing capital punishment," id.-i.e., calls for lemency in the capital senteucing decision. Thus, as the Supreme Court has explained, some typical mitigating circumstances are "the youth of the offender, the absence of any prior conviction, the influence of drugs, alcohol or extreme ennotional disturbance, and even the existence of circumstances which the offender reasonably believed provided a moral justiflcation for his conduct." Roberts v. Louisiana, 431 U.S. at 637. All of these factors are "mitigating factors" because they militate in favor of leniency in the capital sentencing decision.

For purposes of this Article, a mitigating "factor" or "circumstance" should be distinguished from a mitigating "aspect" of a specific defendant's character, record, or offense. An aspect of character, record, or offense is simply an attribute or characteristic of the individual defendant's character, record, or the circumstances of his offense that the defendant can proffer as a mitigating circunstance itself or as evidence of a mitigating circumstance. For example, a defendant could offer proof of his extreme enotional disturbance, and argue that this aspect of his character is in itself a mitigating circumstance. The defendant also could present evidence of his earlier commitment to a mental institution, another aspect of his character, which would tend to support the mitigating circumstance of extreme enıotional disturbance.

26. Woodson v. North Carolina, 428 U.S. at 305.

27. Roberts v. Louisiana, 428 U.S. at 333-34; Woodson v. North Carolina, 428 U.S. at 30405; Jurek v. Texas, 428 U.S. at 271.

28. Roberts v. Louisiana, 428 U.S. at 333-34 ("The constitutional vice of mandatory death penalty statutes [is the] . . lack of focus on the circumstances of the partieular offense and the character and propensities of the offender," and "[e]ven the . . narrowly drawn categories of first-degree inurder in the Louisiana law afford no meaningful opportunity for consideration of mitigating factors presented by the circumstances of the particular crime or by the attributes of the individual offender."); Woodson v. North Carolina, 428 U.S. at 304-05. 
Although the 1976 Cases made it clear that virtually all capital defendants have a constitutional right to receive sentencer consideration of mitigating circumstances, ${ }^{29}$ the cases did not fully define the nature and scope of this right. While declaring unequivocally that a death penalty statute must permit at least some sentencer consideration of mitigating aspects of the defendant's character, record, and offense, the decisions failed to clarify whether the defendant has the constitutional right to present evidence and receive sentencer consideration of all such mitigating circuinstances. ${ }^{30}$

\section{B. Lockett v. Ohio}

Sandra Lockett was charged with and convicted of the capital offense of aiding in the commission of an arned robbery that resulted in a homicide. ${ }^{31}$ In accordance with the Ohio death penalty statute, Lock-

29. In establishing this right, the Court expressly reserved the question whether a mandatory death penalty with no sentencer consideration of mitigating circumstances might be constitutionally permissible in the exceptional case of a murder by a prisoner already serving a life sentence for a previous unrelated unurder conviction. Roberts v. Louisiana, 428 U.S. at 334 n.9; Woodson v. North Carolina, 428 U.S. at 287 n.7, 292 n.25. The Court has contimued to reserve this issue in subsequent decisions. Lockett v. Ohio, 438 U.S. at 604 n.Il; Roberts v. Louisiana, 431 U.S. 633, 637 n.5 (1977) (per curiam). Lower courts have concluded, however, that the constitutional principles that prohibit mandatory death penalty statutes apply equally in the case of a murder by a prisoner serving a life sentence. Graham v. Superior Court, $98 \mathrm{Cal}$. App. 3d 880, 887, 160 Cal. Rptr. 10, 13-14 (1st Dist. 1979); State v. Cline, 397 A.2d 1309, 1311 (R.I. 1979). Contra, Schuman v. State, 578 P.2d 1183, 1186-87 (Nev. 1978). The only possible basis for distinguishing the life prisoner who commits murder from other capital defendants is the possibility that a defendant who is already serving a life sentence may not be deterred from committing a subsequent murder unless the punishment for this second offense were death, and not merely a superfluous additional term of imprisonment. See Gregg v. Georgia, 428 U.S. at 186. This argument assumes that a defendant serving a hife sentence does in fact remain im prison until he or she dies, and thus that the life prisoner is already serving the maximum punishinent short of death. However, in most states, all hfe prisoners have the possibility of parole, see, e.g., N.Y. PENAL LAw $\$ \$ 70.00(3), 70.40$ (McKinney Supp. 1979-1980), and even in those states im which a defendant can be sentenced to life imprisonment without the possibility of parole, such a defendant can still receive a commutation of sentence by the governor. See, e.g., CAL. CoNST. art. VII, $\$ 1$ (commutation power applicable to all offenses and therefore could be exercised in the case of a defendant who has been sentenced to life imprisonment without the possibility of parole under CAL. PENAL CoDE $\S \S$ I90190.4 (West Supp. 1980) and is subject to mandatory capital punishment under CAL. PENAL CODE $\S 4500$ (West Supp. 1980) if he or she commits a subsequent murder). Thus, a mandatory death sentence is not necessary for deterrence: Even a life prisoner has "something to lose"-the possibility of eventual freedom-if he or she commits a murder while in prison. Grahan v. Superior Court, 98 Cal. App. 3d at 887, 160 Cal. Rptr. at 13-14; H. Bedau, The CourTs, The Constitution, and Capital Punishment 49 (1977); Zeisel, The Deterrent Effect of the Death Penalty: Facts v. Faiths, 1976 Sup. CT. Rev. 317, 339. Thus, a murder by a life prisoner is not distinguishable from other capital offeuses for purposes of eighth amendment requirements for sentencer consideration of mitigating circumstances, and this Article will therefore treat all capital offenses alike in discussing eighth amendment requirements.

30. See Lockett v. Ohio, 438 U.S. at 604 (pointing out this uncertainty in the mitigating circumstances requirements established in the 1976 decisions).

31. Id. at 589-93. The precise charge was aggravated murder with the specifications that (1) the murder was "committed for the purpose of escaping detection, apprehension, trial, or punish- 
ett was permitted to present the sentencing judge with a wide range of potentially mitigating evidence concerning her character and history and the nature of her offense. ${ }^{32}$ Lockett's character evidence showed that she was twenty-one years old, of generally good character, and had excellent prospects for rehabilitation. ${ }^{33}$ Psychiatric reports revealed that Lockett had a low I.Q., possibly within the mental retardation range. ${ }^{34}$ Lockett also presented evidence concerning her criminal record, showing that although she had committed minor offenses as a juvenile and two misdemeanors as an adult, she had cominitted no major criminal offenses until the present felony murder..$^{35}$ Lockett's evidence concerning the nature of her offense demonstrated that she had played only a minor role in the robbery and did not participate in the actual killing, and that the killing itself was unintentional. ${ }^{36}$

Although the Ohio statute permitted the sentencing judge to hear this mitigating evidence, it precluded him from considering it except for the himited purpose of determining the existence of the three initigating circumstances enumerated in the statute: (i) victim induceinent; (ii) duress, coercion, or provocation; and (iii) psychosis or mental deficiency primarily causing the commission of the offense. ${ }^{37}$ In the absence of any of these statutorily ellumerated initigating circuinstances, the statute required the sentencing judge to impose a death sentence. ${ }^{38}$ The sentencing judge in Lockett concluded that none of the statutory mitigating circumstances apphed, and sentenced Lockett to death. ${ }^{39}$ The Ohio Supreme Court upheld the conviction and death sentence, ${ }^{40}$ and the Umited States Supreine Court granted certiorari. ${ }^{41}$

In her argument before the Court, Lockett claimed that the Ohio statute unconstitutionally limited jury cousideration of mitigating cir-

ment" in the course of an aggravated robbery, and (2) the murder was committed "while . . . committing, attempting to commit, or fleeing immediately after committing or attempting to commit . . . aggravated robbery." Id. at 589 .

32. See id. at 594. For a detailed summary of this evidence, see Brief for Petitioner at 29-31, Lockett v. Ohio, 438 U.S. 586 (1978) [hereinafter cited as Brief for Petitioner]. The Ohio statute permitted a defendant to present mitigating evidence concerning "the nature and circumstances of the offense and the history, character, and condition of the offender." OHIO REv. Code ANN. \$ 2929.04(B) (Page 1975); see State v. Bell, 48 Ohio St. 2d 270, 281, 358 N.E.2d 556, 564-65 (1976), rev'd, 438 U.S. 637 (1978).

33. Lockett v. Ohio, 438 U.S. at 594; State v. Loekett, 49 Ohio St. 2d 48, 66-67, 358 N.E.2d 1062, 1074-75 (1976), rev'd, 438 U.S. 586 (1978).

34. Lockett v. Ohio, 438 U.S. at 594; Brief for Petitioner, supra note 32, at 31, 58.

35. Lockett v. Ohio, 438 U.S. at 594; Brief for Petitioner, supra note 32, at 58.

36. Lockett v. Ohio, 438 U.S. at 594 n.2; Brief for Petitioner, supra note 32, at 58.

37. OHlo Rev. Code ANN. \& 2929.03(E) (Page 1975); see Lockett v. Ohio, 438 U.S. at 594;

State v. Lockett, 49 Ohio. St. 2 d 48, 66-67, 358 N.E.2d 1062, 1074, rev'd, 438 U.S. 586 (1976).

38. Ohio Rev. CoDe ANN. \$ 2929.03(E) (Page 1975).

39. 438 U.S. at 594.

40. State v. Lockett, 49 Ohio St. 2d 48, 358 N.E.2d 1062 (1976).

41. 434 U.S. 889 (1977). 
cumstances. Lockett argued that the statutorily prescribed sentencing procedure precluded the sentencer from considering such mitigating factors as her age, character, criminal record, lack of specific intent to cause death, and her relatively minor part in the killing ${ }^{42}$ by requiring it to cull from the defendant's mitigating evidence only those factors relevant to the three statutorily prescribed mitigating circumstances.

In an opmion representing the views of a majority of the Court, ${ }^{43}$ Chief Justice Burger held that the Ohio statutory scheme violated the eighth amendinent. The Chief Justice explained that a death penalty statute inust not prevent the sentencer from "considering any aspect of the defendant's character and record or any circuinstances of his offense as an independently mitigating factor."44 Broad sentencer consideration of the "imdependent mitigating weight" of those aspects of character, record, and offense that the defendant has proffered in mitigation, wrote Chief Justice Burger, helps to ensure the rehability re-

42. Lockett v. Ohio, 438 U.S. at 597; Brief for Petitioner, supra note 32, at 58.

43. Although, strictly speaking, Chief Justice Burger's opinion on the mitigating circumstances issue represents only a four-Justice plurality, careful examination of the opinions in Lockett shows that as a practical inatter, the principles espoused in the Chief Justice's opinion represented the opinion of a majority of the Court. See Chenault v. Stynchcombe, 581 F.2d 444, 447-48 (5th Cir. 1978). Seven of the eight participating Justices agreed that Lockett's death sentence had to be vacated. Justices Stewart, Powell, and Steveus concurred in the crucial Part III of the Chief Justice's opinion, establishing the capital defendant's right to sentencer consideration of all mitigating aspects of character, record, and offense. Lockett v. Ohio, 438 U.S. at 606-09. Justice Marshall adhered to his view that the death penalty is categorically unconstitutional, id. at 619 , but indicated his agreement with the Chief Justice's view on initigating circumstances by asserting that the Ohio statute was a "blunderbuss . . . approach to iniposition of the death penalty for certain crimes, [that] wholly fails to recognize the unique individuality of every criminal defendant who comes before its courts." Id. at 620-21. In a view analogous to, but slightly different from, the Chief Justice's view, Justice Blackmun asserted that the state had to allow sentencer consideration of the petitioner's noninvolvement in the actual killing and the degree of her mens rea. Id. at 613-17. Justice Blackmun apparently would require the state to allow sentencer consideration of these two mitigating circumstances, but not necessarily all mitigating circumstances. Justice White expressly rejected the Chief Justice's reason for vacating the death sentence, id. at 622-24, and instead relied on a ground not reaclied by the Chief Justice. He invoked the proportionahty principle, see note 23 and accompanying text supra, asserting that a death sentence for a defendant who did not intend to cause the death of the victim was grossly disproportionate to the crime and served no valid purpose. Lockett v. Ohio, 438 U.S. at 624-28. Alone among the Justices, Justice Rehnquist would have affirmed the death sentence. Id. at 636. Justice Breunan did not take part in the decision of Lockell.

Justice Marshall's reasons for vacating the death sentence, broader than but encompassing the Chief Justice's rationale, suggest that at least five Justices-Stewart, Powell, Stevens, Burger, and Marshall-would vote to overturn the death sentence of a defendant denied the right to present all initigating circumstances of character, record, and offense. This view would also be likely to win the vote of Justice Breunan, who has consistently maintained that the death penalty is per se unconstitutional. E.g., Coker v. Georgia, 433 U.S. 584, 600 (1977) (Brennan, J., eoncurring in the judgment). This Article will therefore refer to the Lockett decision as expressing the views of a majority of the Court, rather than just a plurality.

44. Lockett v. Ohio, 438 U.S. at 607. 
quired in the procedures for imposing the death sentence. ${ }^{45}$ The vice of the Ohio statute was that the sentencing authority could consider initigating factors such as the defendant's age, minor role in the offense, and lack of specific intent to cause deatl only if they slied light on one or more of the statutory mitigating circuinstances. Thus, they could not in themselves affect the sentencing determination. ${ }^{46}$ Even though the sentencing authority could hear the mitigating evidence, the structure of the sentencing procedure prevented the sentencer from giving independent initigating weight to the proffered aspects of cliaracter, record, and offense.

The Lockett decision thus resolved the ambiguity in the 1976 Death Penalty Cases $^{47}$ and inade clear that a capital defendant lias an eighth amendinent right to a sentencing authority with the power to consider any and all aspects of the defendant's character, record, and offense that the defendant wishes to proffer as mitigating circuinstances. ${ }^{48}$ The Lockett decision thus does more than inerely expand the number of factors that inust be considered by a capital sentencing authority; it alters the process by which that authority inust consider those factors. The real significance of the decision lies in its requireinent that the sentencer give all mitigating factors offered by the defendant independent mitigating weight.

The defendant's right to have the sentencing authority "consider" any proffered aspect of character, record, or offense is more than a constitutional prohibition of restrictive rules concerning the admissibility of evidence at a sentencing hearing. It is a right to have the sentencer use such evidence as it sees fit in deciding whether the defendant merits leniency. The Lockett Court's discussion of this independent initigating weight requirement, unfortunately, is all too brief, and leaves its application to other state sentencing statutes unclear. The decision merely announces the existence of the requirement and applies it to the facts of the case. Similarly, in Bell $v$. Ohio, ${ }^{49}$ a companion case to Lockett, the Court simply applied the primciples established in Lockett to the facts of the Bell case to find that Bell had been unconstitutionally sentenced to death under the Ohio statute. ${ }^{50}$ The Court's subsequent death penalty decisions have not shed any further light on the Lockett

45. Id. at 605 . The Chief Justice alluded to the common practice in noncapital cases of individualized sentencing that relies on a wide variety of evidence about the character and background of the defendant and the nature of his offeuse. He stated that a capital sentencing proceeding was an a fortiori occasion for such individualized sentcncing. Id.

46. Id. at $604,607-08$.

47. See note 30 and accompanying text supra.

48. See note 25 supra.

49. 438 U.S. 637 (1978).

50. Id. at 642-43. 
imdependent mitigating weight requirement. ${ }^{51}$

The imdependent mitigating weight requirement can, of course, be narrowly defined in terms of the Ohio statute struck down in Lockett and Bell. Under such an interpretation, a state death penalty statute violates Lockett if, like the Ohio statute, it estabhshes an exclusive roster of mitigating circumstances and requires that the sentencer consider proffered mitigating evidence solely in the context of determining the existence of those circumstances. However, both the general language used by the Court in announcing this requirement in Lockett and the doctrimal roots of the imdependent mitigating weight requirement suggest a far broader ineaning.

In Part II, we explore the scope of the independent mitigating weight requirement by applying it to the death penalty statutes of two states, Texas and Georgia. ${ }^{52}$ On their surface, these statutes differ significantly from the Ohio statute invalidated in Lockett, but closer examination reveals that each fails to meet the constitutional standards imposed by that decision. The two case studies also illustrate a problein that exists in states that have statutes that differ in form froin the Ohio law: an unwillingness on the part of the lower courts to look beyond the surface differences between the statutes and apply the general primciples imphicit in the Lockett decision.

51. All but one of the more recent Supreme Court decisions have concerned other aspects of capital sentencing. See Adams v. Texas, 100 S. Ct. 2521 (1980) (application of statutorily prescribed procedure for juror qualification in capital cases violated doctrine of Witherspoon v. Illinois, 391 U.S. 510 (1968)); Beck v. Alabama, 100 S. Ct. 2382 (1980) (imposition of death sentence violated eighth amendment where jnry was not permitted to consider verdict of guilt of lesser included noncapital offense); Godfrey v. Georgia, $100 \mathrm{~S}$. Ct. 1759 (1980) (statutory aggravating circumstance unconstitutionally vague as construed and applied); Presnell v. Georgia, 439 U.S. 14 (1978) (per curiam) (imposition of death sentence violated due process where one of the elements of capital murder had never been found by sentencing authority but was found by appellate court on the basis of its independent review of record). In the one recent decision relating to the right to present and receive consideration of mitigating circumstances-Green v. Georgia, 442 U.S. 95 (1979) (per curiam) - the Court held that strict application of hearsay requirements to exclude mitigating evidence in capital sentencing learings violated due process. See notes 220-28 and accompanying text infra. Although reiterating the crucial nature of the defendant's Lockett right to present any and all mitigating evidence, see 442 U.S. at 97 , the brief decision did not elaborate on the meaning of the independent mitigating weight requirement.

52. It is, of course, hardly coincidental that the two statutes chosen for this analysis are laws sustained in the 1976 Death Penalty Cases. Because these statutes exemplify the constitutional standards einployed by the Supreme Court in the 1976 decisions, they can be used to examine the extent to which Lockett expands the requirements established in the earlier decisions. Moreover, because the Court rejected constitutional attacks on these statutes in the 1976 Cases, they have served as inodels for death penalty laws in other states. See, e.g., State v. White, 395 A.2d 1082, 1085 (Del. 1978) (observing that DEL. CODE ANN. tit. 11, § 4209 (1977) "was obviously fashioned upon the Georgia statute approved by the Umited States Supreme Court in Gregg"); OR. REv. STAT. $\$ 163.116$ (1979) (nodeled after the Texas law upheld in Jurek v. Texas). 
II

\section{The Nature and Scope of Lockett ReQuirements}

\section{A. The Texas Statute}

The Texas death penalty statute may appear at first to be less constitutionally suspect than the Ohio statute. It does not expressly enumerate mitigating circumstances, and has been construed by the state courts as permittimg wide-ranging sentencer consideration of mitigating factors. Closer examination of the Texas statute reveals, however, that it cannot survive eighth amendment scrutiny under the independent mitigating weight principle any better than the Ohio statute struck down im Lockett. That examination requires us to probe further into the meaning of the Lockett requirement that the sentencer be able to give independent mitigating weight to any proffered mitigatimg circuunstances.

\section{The Statutory Scheme}

Under the Texas death penalty statute, ${ }^{53}$ the defense and prosecution in a capital sentencing hearing can present any evidence relevant to sentence. ${ }^{54}$ The sentencing jury is then directed to answer three questions:

(1) whether the conduct of the defendant that caused the death of the deceased was committed deliberately and with the reasonable expectation that the death of the deceased or another would result; 55

(2) whether there is a probability that the defendant would commit criminal acts of violence that would constitute a continuing threat to society; ${ }^{56}$ and

(3) if raised by the evidence, whether the conduct of the defendant in killing the deceased was unreasonable in response to the provocation, if any, by the deceased. ${ }^{57}$

The jury must determine whether the state has proved beyond a rea-

53. Tex. Code Crim. Proc. AnN. art. 37.071 (Vernon Supp. 1980).

54. The statute provides that "evidence may be presented as to any matter that the court deems relevant to sentence." Id. art. 37.071(a). For a discussion of the precise scope of the capital defendant's right to present evidence of mitigating circumstances under Texas law, see notes 72-75 and accompanying text infra.

55. Tex. Code Crum. Proc. ANN. art. 37.071(b)(1) (Vernon Supp. 1980). In a scathing criticism of the Jurek decision, Professor Charles Black argues that the first statutory question does not bear any rational relevancy to the issue of sentencing, but rather bears on issues of factual guilt that should have been resolved before the defendant was convicted. Black, Due Process for Death: Jurek v. Texas and Companion Cases, 26 CATH. U.L. REv. 1, 13-16 (1976).

56. TeX. CODE CRIM. Proc. ANN. art. 37.071(b)(2) (Vernon Supp. 1980). Professor Black has strenuously argued that this question fairly invites a due process challenge on void-for-vagueness grounds, since no person could discern any clear content in the words "probability . . . beyond a reasonable doubt" and "criminal acts of violence." Black, supra note 55, at 4-6.

57. TeX. Code Crim. Proc. ANN. art. 37.071(b)(3) (Vernon Supp. 1980). Professor Black has pointed out that this question, like the first statutory question, concerns an issue of factual 
sonable doubt that the answer to each of the questions asked is yes. ${ }^{58}$ If the jury unanimously answers each of the questions affirmatively, the trial judge must sentence the defendant to death. ${ }^{59}$

In establishing this structure for capital sentencing judgment, the Texas statute does not expressly provide for sentencer consideration of mitigatimg circumstances. ${ }^{60}$ However, im Jurek $v$. State, ${ }^{61}$ the Texas Court of Criminal Appeals interpreted the statute as allowing consideration of a wide range of mitigating factors. The court took the view that the jury, in answering question number two concerning the likelilood of the defendant's contmumg to be a "threat to society," can consider sucli factors as the range and severity of the defendant's earlier criminal conduct, his age, and the possibility that lie committed the capital offense under duress, the domination of another person, or some extreme mental or emotional pressure. ${ }^{62}$

The Texas court's construction of the statute figured prominently in the United States Supreme Court's decision in the same case, Jurek $v$. Texas, ${ }^{63}$ upliolding the state statute agamst an eighth amendment attack. In holdimg that the statute avoids the arbitrariness condemned in Furman by providing for jury consideration of aggravatimg and mitigatmg circumstances, ${ }^{64}$ the Supreme Court plurality found that the second statutory question, as construed by the state court, permits jury consideration of mitigatimg circumstances. ${ }^{65}$

The state court construction of the statute in Jurek was also a key factor in the Texas Court of Criminal Appeals' rejection of a Lockett

guilt that should be resolved in the guilt phase of the trial rather than at the sentencing hearing. Black, supra note 55, at 4-5.

58. Tex. Code Crim. Proc. ANN. art. 37.071(c)-(d) (Vernon Supp. 1980). Although the jury must be unanimous in order to return an affirmative finding to any of the questions, it can answer "no" to a question if ten of the twelve jurors vote for a negative finding. Id. art. 37.071 (d).

59. Id. art. $37.071(\mathrm{e})$.

60 . Jurek v. Texas, 428 U.S. 262, 272 (1976) ("The Texas statute does not explicitly speak of mitigating circumstances; it directs only that the jury answer three questions.").

61. 522 S.W.2d 934 (Tex. Crim. App. 1975), aff'd, 428 U.S. 262 (1976).

62. 522 S.W.2d at 939-40. The defendant in Jurek had claimed that the three-question statutory scheme was too vague to give adequate guidance to the jury. The Texas Court of Criminal Appeals rejected this claim, declaring that the factors relevant to a decision on the death penalty are too complex to permit a simple formula. Id. at 939 . The court then went on to state that there are nevertheless some factors, such as the defendant's age and criminal record, "which are readily apparent and are viable factors for the jury's consideration." Id.

63. 428 U.S. 262 (1976).

64. Id. at 276.

65. Id. at 272-74. Reviewing the Texas courts' interpretation of the second statutory question, the plurality read the decisions in Jurek v. State, 522 S.W.2d 934 (Tex. Crim. App. 1975), and Smith v. State, No. 49,809 (Tex. Crim. App. Feb. 18, 1976), as establishing a defendant's right "to bring to the jury's attention whatever mitigating circumstances le may be able to show." 428 U.S. at 272 . 
challenge three years later. In Adams $v$. State,${ }^{66}$ the defendant claimed that the Texas statutory scheme violated Lockett by unduly restricting the jury's discretion in deciding whether the death penalty is appropriate to a given offense. ${ }^{67}$ Adains argued that whenever the jury answered the statutory questions in the affirmative, the statute unconstitutionally prevented the jury from exercising leniency even if it believed that "under all the circunstances the defendant does not 'deserve' a sentence of death." 68 Adams conceded that under Surek v. State ${ }^{69}$ a capital defendant in Texas inay offer "any relevant mitigating evidence." $\mathrm{He}$ argued, however, that mitigating factors are "of no avail" if the evidence in the case requires affirmative answers to the punishment questions. ${ }^{71}$ Adams essentially argued that to satisfy Lockett, the jury must have the power to invoke any proffered aspect of the defendant's character, record, or offense as a reason in and of itself for mitigating the defendant's sentence.

The state court in Adams read Lockett as holding "that any relevant mitigating evidence offered by the defendant inust be considered by the sentencing authority,"72 and summarily declared that "Texas practice is in accord with this holding." 73 This characterization of Texas practice is questionable, since the state sentencing procedures appear to impose significant restrictions on both the defendant's ability to present all mitigating circumstances ${ }^{74}$ and the jury's ability to fully consider those circuinstances. ${ }^{75}$ Even inore important, however, the Texas

66. 577 S.W.2d 717 (Tex. Crim. App. 1979), rev'd in part on other grounds, 100 S. Ct. 2521 (1980). The Texas Court of Criminal Appeals' decision in Adams addressed several issues, including a Lockett challenge to the Texas statute and a claim that the jury selection procedure used in the case violated the doctrine of Witherspoon v. Illinois, 391 U.S. 510 (1968). The Supreme Court's grant of certiorari was limited to the Witherspoon issue and the Court reversed the conviction solely on this ground. See $100 \mathrm{~S}$. Ct. at 2525 .

67. 577 S.W.2d at 729-30.

68. Id. at 729 .

69. 522 S.W.2d 934 (Tex. Crim. App. 1975), aff'd, 428 U.S. 262 (1976).

70. State v. Adams, 577 S.W.2d at 729 (emphasis added).

71. Id.

72. Id. at 730 (emphasis added).

73. Id.

74. Although the Texas Court of Criminal Appeals has construed the statute to permit introduction of all mitigating evidence, Quinones v. State, 592 S.W.2d 933, 947 (Tex. Ct. Crinn. App.), cert. denied, 101 S. Ct. 256 (1980); Hovila v. State, 562 S.W.2d 243 (Tex. Ct. Crim. App. 1978), cert. denied, 439 U.S. 1135 (1979), the case law demonstrates that the Texas Courts in practice are restricting mitigating evidence to information that is relevant to the statutory questions. Davis, Texas Capital Sentencing Procedures: The Role of the Jury and the Restraining Hand of the Expert, 69 J. CRIM. L. \& Criminology 300, 302 \& n.26 (1978); Dix, Appellate Review of the Decision to Impose Death, 68 Geo. L.J. 97, 154-55 (1979); see, e.g., Hovila v. State, 562 S.W.2d 243, 249 (Tex. Crim. App. 1978), cert. denied, 439 U.S. 1135 (1979) (upholding trial court's determination that defendant could not present certain mitigating evidence because the evidence was not relevant to the statutory questions).

75. Under the Texas sentencing procedure, the jury instructions present the statutory ques- 
court in Adams completely ignored the essence of the Lockett decision-that the sentencer not only must be allowed to hear all mitigating evidence, but also must be allowed to give each proffered mitigating circumstance independent mitigating weight. Failing to appreciate Adams' argument that the narrowly focused punishment questions were madequate vehicles for jury consideration of all mitigating aspects of character, record, and offense, the court held that these questions served to "give guidance to the jury regarding those factors about the crime and the defendant that the State, representing organized society, deems particularly relevant to the sentencing decision." thus avoided the more basic question whether the guidance provided by the punishment questions prevents the jury froin relying on mitigating factors other than those specifically relevant to the statutory questions in determining whether the death penalty should be miposed. ${ }^{77}$

tions in the precise language of the statute, and the defendant is not entitled to an instruction informing the jury of its ability to consider mitigating circumstances in answering the second question. See Quinones v. State, 592 S.W.2d 933, 947 (Tex. Crim. App. 1980), cert. denied, 101 S. Ct. 256 (1980). The jury cannot be presuined to give full consideration to mitigating circuinstances unless it is informed of its ability to do so. For further discussion of the central role of jury instructions in permitting effective sentencer consideration of mitigating circumstances, see Part II B infra. The Texas Court of Criminal Appeals has declared that "[t]he jury can readily grasp the logical relevance of mitigating evidence to the issue [in the second statutory question] of whether there is a probability of future criminal acts of violence." Quinones v. State, 592 S.W.2d at 947. However, neither the second statutory question nor any other part of the statute expressly refers to mitigating circunstances, Jurek v. Texas, 428 U.S. at 272 , and the second statutory question appears on its face to refer to matters very different from the existence of mitigating circumstances. See The Supreme Court, 1975 Term, 90 Harv. L. Rev. at 71 . Moreover, as Professor Charles Black has pointed out, the second statutory question is couched in language that is vague and confusing to a lay jury. Black, supra note 55, at 4-6. Thus, there appears to be good reason to doubt that Texas sentencing juries will perceive in all cases the proper role of mitigating circuinstances in the sentencing process, and will effectively consider the mitigating factors proffered by the defendant.

76. Adams v. State, 577 S.W.2d at 730.

77. Although the Supreme Court lias on two occasions considered the Texas mitigating circuinstances provision, the Court has not as yet resolved the question of whether the statute precludes the sentencer from giving independent mitigating weight to proffered mitigating factors. In Jurek, the plurality read the state court's decisions in the same case and in Smith v. State, Tex. Crim. App. No. 48,809 (Feb. 18, 1976), as allowing the defendant to introduce all mitigating factors and as permitting the jury "to consider whatever evidence of mitigating circumstances the defense can bring before it." 428 U.S. at 262,273 . However, the Jurek plurality did not address the separate question of whether a Texas jury can not only hear and consider evidence but also give independent mitigating weight to proffered aspects of character, record, and offense.

In Lockett, the Supreine Court noted that the Texas law had not "clearly operated" at the time of the Jurek decision to prevent the jury from considering any proffered factor as an independently mitigating circumstance. 438 U.S. at 606-07. However, this Lockett reference to the Texas statute did not in any way hold that the law conforms to Lockett requirements, and indeed could not be so construed, since the Texas statute was not before the Court in Lockett. See note 24 supra. 


\section{The Texas Statute and the Lockett Independent Mitigating Weight Requirement}

The Ohio statute invalidated in Lockett allowed capital defendants to present evidence of mitigating aspects of character, record, and offense, and Sandra Lockett presented evidence of this type in her sentencing hearing. ${ }^{78}$ That the Supreme Court nevertheless struck down the Ohio statute and Lockett's death sentence emphasizes the constitutionally significant distimction between allowing the defendant to present mitigatimg evidence and allowing the sentencer to consider mitigating circuinstances. A defendant presents evidence of aspects of character, record, or offense that he wishes to proffer as or in support of mitigating circumstances. The sentencer then considers the mitigating weight of a proffered characteristic of the defendant or his offense by evaluating whether this factor calls for leniency. The constitutional flaw in the Ohio statute was that the legislature had made a categorical decision as to which circuinstances of character, record, or offense could serve as sufficient grounds for leniency in capital cases. Although the defendant was free to proffer almost any aspect of her character, record, or offense as evidence in support of her plea for leniency, the statute unconstitutionally limited the use to which the sentencer could put that evidence: The sentencer could use such evidence only to determine the existence of one or nore of the three statutory mitigating circumstances. The statute impermissibly prevented the sentencer from supplementing the legislative list by considering nonstatutory circumstances that, in the sentencer's view, might constitute independent and sufficient grounds for mitigating sentence. In invalidatimg this statute, the Lockett decision established that a capital sentencing authority nust be allowed to look beyond the legislative selection of mitigating circuinstances and consider the independent mitigating weight of nonstatutory factors.

The Texas statutory procedure plainly violates the independent mitigating weight requirentent. Like Ohio judges before Lockett, Texas sentencing juries are permitted to consider mitigating evidence solely for the purpose of resolving three statutorily defined issues-the defendant's intent to cause the death of the victim, the contmuing dangerousness of the defendant, and the existence of provocation by the victim. Insofar as mitigating evidence offered by the defendant and admitted by the trial court cannot help to answer any of these questions, the jury cannot consider and give mitigating effect to this evidence. ${ }^{79}$ And, as was true of the Ohio law, the categories established by

78. See notes $32-36$ and accompanying text supra.

79. In fact, since the Texas statute expressly limits the jury's authority at sentencing to answering "yes" or "no" to the three statutory questions, a jury that did give independent weight to 
the statutory questions are not sufficiently broad to allow the sentencer to consider any and all factors that it might deem relevant to sentence.

For example, a Texas sentencing jury could not mitigate sentence on the basis of a defendant's mental illness, a factor that other state statutes expressly designate as mitigating. ${ }^{80}$ Since inental illness would not disprove the continuing dangerousness of a defendant (and, indeed, would tend to indicate that the defendant would continue to be dangerous), that factor would not result in a negative answer to the second statutory question; thus the statute precludes consideration of it im mitigation of the defendant's sentence. ${ }^{81}$ Like the Ohio statute struck down in Lockett, the Texas statute unconstitutionally deprives the defendant of the mitigating effect of any factors that would not produce negative answers to the narrow statutory questions, and deprives the sentencing authority of the ability to give imdependent mitigating weight to any and all proffered mitigating factors.

Thus, a straightforward comparison of the Texas and Ohio death penalty laws reveals that the Texas statute violates Lockett. The constitutional flaw in the Texas law is even more striking when the Texas scheine of jury questions is examined in relation to the eighth annendment origins of Lockett's mdependent mitigating weight requirement.

\section{The Texas Statute in Light of the Jurisprudential Basis of the Independent Mitigating Weight Requirement}

The jurisprudential basis of the Lockett independent mitigating weight requirement hes in the bifurcated eighth amendment analysis that the Court applied in the 1976 Death Penalty Cases to evaluate the constitutional validity of capital punishment. In order to pass the test of the eighth ainendment, the plurality held, the death penalty inust be consistent with two broad principles. First, it inust be im hannony with "the evolving standards of decency that mark the progress of a maturing society." ${ }^{2}$ Second, to ensure that the penalty is not excessive, it inust be measured against the moral and jurisprudential criteria inherent in the eighth ainendment and reflected im "the dignity of inan." 83

evidence that did not address the statutory questions would be acting "lawlessly," Woodson v. North Carolina, 428 U.S. at 303, and "disregarding the jury's instructions," Roberts v. Louisiana, 428 U.S. at 335.

80. E.g., Cal. Penal Code ANn. $\$ \S 190.3($ d), (h) (West Supp. 1980); lll. AnN. Stat. ch. 38, \$ 9-1(c)(2) (Smith-Hurd Supp. 1980); WASH. REv. CoDE \$\$ 9A.32.045(2)(b), (f) (1979).

81. The Texas Court of Criminal Appeals held that wide-ranging mitigating evidence was admissible under the statute only because that evidence might be relevant to question number two, Jurek v. State, 522 S.W.2d at $939-40$, and the 1976 plurality upheld the Texas statute against an eighth amendment challenge precisely because question number two could serve that purpose. Jurek v. Texas, 428 U.S. at $272-74$.

82. Gregg v. Georgia, 428 U.S. at 173 (quoting Trop v. Dulles, 356 U.S. 86, 101 (1958)).

83. Gregg v. Georgia, 428 U.S. at 173, 182. 
In determining that the death penalty satisfied "evolving standards of decency," the plurality relied heavily on the decision of a majority of state legislatures to reenact the death penalty after Furman and on the general pattern of jury decisions imposing the death penalty. ${ }^{84}$ Thus, in holding that the death penalty was, at least as a general matter, consistent with responsible public attitudes and values, the plurality did not atteinpt to identify those values directly but chose instead to rely on the decisions of legislatures and juries, the two institutions that in its judgment best represented those values and attitudes. Expressing confidence that a jury in an individual case would represent public attitudes and values in determining whether death is the appropriate punishment ${ }^{85}$ the plurality einphasized that "[ $\left.t\right]$ he jury . . . is a significant and reliable objective index of contemporary values," and that "one of the most important functions any jury can perform in making . . . a selection [between life imprisonment and death for a defendant convicted in a capital case] is to maintain a link between community values and the penal system." "\$86

The evolving standards of decency principle thus supplies the constitutional source of a state legislature's authority to enumerate mitigating circumstances in a statute and thereby designates the factors that should be considered reasons for finding a death sentence inappropriate. In enumerating those factors, the legislature applies public attitudes to determine that such factors as the defendant's emotional disturbance or lack of a criminal record are reasons for leniency in the individual case. But the public attitudes principle simultaneously explains why the sentencing jury, which is also a medium of public attitudes, must be allowed in an individual case to look beyond the statutory roster of mitigating circumstances and consider factors other than those specifically designated by the legislature. ${ }^{87}$ The jury $^{88}$ in a

84. Id. at 179-82.

85. See Woodson v. North Carolina, 428 U.S. at 295-96; Gregg v. Georgia, 428 U.S. at 18182.

86. Gregg v. Georgia, 428 U.S. at 181 (quoting Witherspoon v. Illinois, 391 U.S. 510, 519 n.15 (1968)).

87. Moreover, as a practical matter, the legislature cannot list every possible mitigating factor within the body of a statute. See People v. District Court (Lohr), 196 Colo. 401, 407, 586 P.2d 31, 35 (1978), cert. denied, 440 U.S. 924 (1979) (statutory enumeration of mitigating circumstances could not include the "host of "factors too intangible to write into a statute" "); Liebman \& Shepard, supra note 20 , at 782 .

88. The "public attitudes" principle also demonstrates that the capital sentencing process must involve a jury and cannot be left solely to a sentencing judge. A jury is by definition a "cross-section of the community," representing community values, Ballew v. Georgia, 435 U.S. $223,229-30$ (1978), and inherently providing the requisite link to public attitudes and contemporary community values. Witherspoon v. Illinois, 391 U.S. 510, 519 (1967); see Woodson v. North Carolina, 428 U.S. at 295-96; Gregg v. Georgia, 428 U.S. at 181-82, 190-92. An individual sentencing judge cannot provide this type of link to counmunity values and therefore cannot satisfy 
capital case performs the crucial function of assessing whether the case presents circumstances that, although not enumerated in the statute, nevertheless make death an inappropriate penalty. By requiring that a sentencer consider all mitigating circumstances proffered by a defendant, the Lockett independent mitigating weight requirement thus serves to ensure that an individual death sentence is consistent with public attitudes and evolving standards of decency.

The second primciple upon which the plurality in the 1976 Cases relied is that of the dignity of man. This concept, as applied in the 1976 Cases, imposes two restrictions: A penalty is unconstitutionally cruel and unusual if it is inflicted without some valid penological purpose, ${ }^{89}$ and is unconstitutionally excessive if it is disproportionate to the crime for which it is imposed. ${ }^{90}$

The plurality in the 1976 Cases held that the death penalty was justified constitutionally because it could serve two penological purposes: retribution and deterrence. ${ }^{91}$ The plurality concluded that the

the eighth amendment requirement that all death sentences be consistent with public attitudes and evolving standards of decency. $C f$. Duncan v. Louisiana, 391 U.S. 145, 156 (1968) (involveinent of jury in capital sentencing reflects "a reluctance to entrust plenary powers over . . . life [and death] . . t to one judge or a group of judges").

The death penalty statutes of soine states provide that the sentencing determination is to be made entirely by a judge without any jury imvolvement. E.g., ARIz. REv. STAT. ANN. § 13-703(B) (Supp. 1980); Neb. Rev. Stat. § 29-2522 (1979); Ohio Rev. Code AnN. \$\$ 2929.03(C), (E) (Page 1975). Courts in these states and Mr. Justice Rehnquist, sitting as Circuit Justice, have concluded that statutory schemes of this type are permissible because a capital defendant does not have a constitutional right to a jury in the sentencing hearing. Richmond v. Arizona, 434 U.S. 1323, 1325 (Rehnquist, Circuit Justice, 1977); State v. Watson, 120 Ariz. 441, 447, 586 P.2d 1253, 1259 (1978); State v. Simants, 197 Neb. 549, 558-59, 250 N.W.2d 881, 887-88, cert. denied, 434 U.S. 878 (1977). However, the analysis in these opinions is questiouable. The state courts and Mr. Justice Rehnquist concluded that the Supreme Court's decision in Proffitt v. Florida demonstrates that a capital defendant does not have a constitutional right to jury involvement in the sentencing determination. In Proffit, the Court approved the Florida statutory scheme under which the jury's sentencing judgment is advisory only, and the ultimate determimation is made by the sentencing judge. 428 U.S. at 248-49, 251-53. However, the Proffit Court emphasized that a Florida capital jury's recommendations concerning sentence have a signiflcant influence on the trial judge's final determination. $I d$. at 249-50. In contrast, the statutory schemes of Arizona, Nebraska, and Ohio do not permit the jury any involvement whatsoever, and therefore - unlike Florida - completely preclude representation of public attitudes and the conscience of the community in the capital sentencing decision. Thus, the Proffitt decision does not determine the constitutionality of these other states' statutory schemes. Indeed, in two post-Proffitt cases cliallenging a sentencing scheme that relegated the sentencing determination entirely to a judge, a majority of the Supreme Court expressly reserved the question of the constitutionality of such a statutory scheme. See Bell v. Ohio, 438 U.S. at 642 n.*; Lockett v. Ohio, 438 U.S. at 609 n.16. The Court thereby implicitly demonstrated that Proffitt did not resolve the constitutionality of a death penalty scheme that entirely excludes jury involvement in the sentencing judgnent.

89. Gregg v. Georgia, 428 U.S. at $173,182-83$.

90. Id. at $173,187$.

91. For a detailed analysis of the vahidity of the plurality's conclusion that capital punishment furthers the ends of retribution and deterrence, see H. BEDAU, supra note 29, at 116-19; Liebman \& Shepard, supra note 20, at 767-71; Zeisel, supra note 29. Cf. Commonwealth v. 
death penalty could properly express and reflect a society's moral outrage at murder, and thus could serve the purpose of retribution for that crime. $^{92}$ Further, in the absence of any conclusive data on the deterrent value of the death penalty, the plurality deferred to the legislative judginent that deatli sentences did deter at least some types of murders and some types of murderers. ${ }^{93}$

The plurality considered the dignity of man principle solely in the context of determining the categorical validity of capital punishment. ${ }^{94}$ As a corollary, however, the 1976 Cases offer strong support for the view that a state statute must also permit the sentencer to deterinme whether the dignity of man test justifies the death penalty in each imdividual case. If death penalty statutes are constitutionally permissible because executions inay fulfill retributive and deterrent purposes, a state statute must not inhibit the sentencer from determining whether the execution of a particular defendant will serve those purposes. This notion links the jurisprudence of the 1976 Cases with the independent mitigating weight requirement of Lockett. The 1976 plurality explamed in Woodson v. North Carolina that the "fundamental respect for humanity underlying the Eighth Amendment . . . requires consideration of the character and record of the individual offender and the circumstances of the particular offense as a constitutionally indispensable part of the process of inflicting the penalty of death."95 The emphasized language from Woodson seems to refer to the concept of human dignity or dignity of man embraced by the saine plurality on the same day in Gregg v. Georgia. ${ }^{96}$ Thus, in requiring state statutes to perinit full sentencer consideration of the circumstances of a particular defendant's character, record, and offense - thereby anticipating Lockett - the 1976 plurality saw such individual sentencing consideration as the instrument of its dignity of man test.

The plurality was concerned that unless the sentencer could consider the possibility of "compassionate or mitigating factors stemming

O'Neal, 369 Mass. 242, 251-62, 339 N.E.2d 676, 681-87 (1975) (Tauro, C.J., concurring) (comprehensive discussion of the possible penological justifications for capital punishment, published prior to the 1976 Death Penalty Cases and reaching conclusions opposite to those reaclied by the 1976 plurality).

92. Gregg v. Georgia, 428 U.S. at 183-84. As commentators have poimted out, the plurality relied on two different theories of retribution: the pure retribution or revenge principle that finds its roots in the Old Testament command of "an eye for an eye," and the utilitarian concept of retribution that justifies punishment by declaring that such forms of institutional revenge are necessary to ensure that citizens will not take the law into their own hands and personally satisfy their desire for vengeance. The Supreme Court, 1975 Term, 90 HARv. L. REv. at 65-66 \& n.25. For a discussion of these theories of retributive justice, see Radim, supra note 23, at 1049-56.

93. Gregg v. Georgia, 428 U.S. at $185-87$.

94. See text accompanying notes 82-86 supra.

95. 428 U.S. at 304 (einphasis added).

96. 428 U.S. at 173,182 . 
from the diverse frailties of humankind," capital defendants would be treated not as unique human beings, but as a "faceless, undifferentiated mass to be subjected to the blind infliction of the penalty of death."97 The plurality thereby linked consideration of individual mitigating factors to the prevention of inhumane punishment, and thus to the fulfillment of the dignity of man principle. ${ }^{98}$ Lockett reaffirmed this theory. Quoting from the 1976 decisions, the Lockett Court again linked consideration of mitigating circumstances to the "fundamental respect for hunianity" embodied in the eighth amendment, ${ }^{99}$ and thus to the dignity of man principle. The 1976 decisions and Lockett therefore demonstrate that one of the purposes of sentencer consideration of mitigating circumstances is to determine whether an individual death sentence is im accord with such concepts. And, as we have seen, the dignity of man principle is satisfied only to the extent that the death penalty rests on penological justifications. Accordingly, a death penalty statute must not prevent the sentencer from considering the mitigating circuunstances proffered by the individual defendant and thereby froin determining whether the execution of that defendant would further retribution or deterrence. ${ }^{100}$ An aspect of a capital defendant's character, record, or offense can therefore be mitigating and nuerit nuitigating weight if it serves to demonstrate that the execution of that defendant would serve neither retribution nor deterrence and therefore would not comport with the dignity of man.

By so identifying the jurisprudential roots of the independent mitigatimg weight requirement, we can define more precisely the constitutional deficiency of the Ohio statute struck down in Lockett. Under the Ohio statute, the sentencer could hear all mitigating evidence but could not treat nonstatutory factors as independent bases for exercising leniency. This type of sentencing schene prevented the sentencer froin determining that a particular nonstatutory factor was, according to conteinporary values, a reason for exercising leniency. The structure of the Ohio sentencing process also prevented the sentencer from effec-

97. 428 U.S. at 304.

98. See id. at 304-05; Gregg v. Georgia, 428 U.S. at 182-83.

99. 438 U.S. at 604.

100. Before Lockett, commentators recognized this principle as implicit in the 1976 decisions. Liebman \& Shepard, supra note 20, at 778, 785; The Supreme Court, 1975 Term, 90 HARv. L. Rev. at 75 n.78. As the textual discussion las shown, the Lockett decision lias provided far clearer evidence of this requirement.

In examining the validity of death sentences imposed in individual cases, several lower court judges have considered the extent to which a death sentence for the particular defendant would further the purposes of retribution or deterrence. See, e.g., Riley v. State, 366 So. 2d 19, 22 n.5 (Fla. 1978); State v. Sonnier, 379 So. 2d 1336, 1366-67 (La. 1979) (Dennis, J., concurring and dissenting), modiffed on rehearing, 379 So. 2d 1368 (1980); State v. Williams, 205 Neb. 86, -, 287 N.W.2d 18, 31-36 (1979) (Krivoslıa, C.J., concurring and dissenting). 
tively considering nonstatutory mitigating factors for the purpose of determining the retributional and deterrent value of an individual death sentence. Even though the sentencer could hear evidence of a particular nonstatutory factor, the sentencer could not use such evidence to decide that application of the death sentence in the particular case would not further the purposes of retribution and deterrence and therefore would not comport with the dignity of inan.

These principles are best illustrated by considering the precise effect of the Ohio sentencing structure on one of the mitigating circumstances proffered by the defendants in both Lockett and its companion case, Bell: nonparticipation in the actual killing. ${ }^{101}$ The Ohio statute allowed the defendants to introduce evidence of their nonparticipation, but did not permit the sentencer to consider that factor in determining the sentence to be imposed. The constitutional defect created by this restriction was twofold. First, the sentencer could not consult the public attitudes of which it was presumably the representative to decide that nonparticipation was a circuinstance calling for leniency. Second, it could not use nonparticipation to determine whether the execution of the defendant would serve either retributional or deterrent purposes. The criminal law, of course, can seek retribution both from a person who performs a proscribed act and froin one who only participates in other acts that lead to or in some way support the proscribed act. ${ }^{102}$ But the degrees of moral culpability that attach to the criminal behavior of these two people inay be very different: The behavior of the person who does not commit the actual killing is likely to invoke significantly less public outrage than that of the killer himself. Thus, in order for the degree of retribution demanded to be appropriate, any moral assessment of a criminal act requires a careful exammation of the criminal's state of mind at the time of the act. ${ }^{103}$ The deterrent value of the death penalty also depends on the situation presented. In the 1976 Cases, the plurahty suggested that the deterrent value of executing a particular defendant depends on the ability of potential murderers the circumstances or nature of whose potential crimes resemble those of the defendant to be deterred. ${ }^{104}$ Whatever the deterrent value of executing an intentional killer, there is serious doubt as to whether

101. Bell v. Ohio, 438 at 639-41; Lockett v. Ohio, 438 U.S. at 589-93, 597.

102. See generally W. LaFAVE \& A. ScotT, HaNDBooK on Cruminal Law 495-527, 553-54 (1972).

103. See Lockett v. Ohio, 438 U.S. at 613-17 (Blackmun, J., concurring) (capital sentencing procedure must allow sentencing authority to consider "the defendant's degree of partieipation in the homicide and the nature of his mens rea in regard to the commission of the homicidal act" in determining whether death sentence is appropriate).

104. 428 U.S. at 185-86; see Riley v. State, 366 So. $2 d$ 19, 22 n.5 (Fla. 1978); Liebman \& Shepard, supra note 20 , at $813-16$. 
the threat of the death penalty will deter a person who, though contemplating a criminal act that might lead to a killing or a dangerous felony that could create liability for murder, is not himself contemplating a killing. ${ }^{105}$ The sentencer's consideration of whether imposing the death penalty on one who has committed an unintentional killing will liave any deterrent value may lead the sentencer to decide not to impose the penalty in such a case. Ohio's statute, by not allowing the sentencer to rely on this consideration in inaking its decision, undercut the eiglth amendment principle of the dignity of man.

Thus, the defendant's constitutional right to have the sentencer give independent mitigating weight to all proffered aspects of character, record, and offense has two sources. First, the defendant is entitled to a sentencer who is free to give voice to contemporary social attitudes and values by using any proffered mitigating evidence to support the existence of circuinstances in the individual case that, in the sentencer's view, argue against execution. Second, the defendant is entitled to have the sentencer mitigate sentence on the basis of any proffered circunstances that, in the sentencer's view, reduce or negate either the retributional or the deterrent value of a deatli sentence for the individual defendant.

\section{Considering the Texas Statute in Light of the Rationale for the Independent Mitigating Weight Requirement}

The constitutionality of the Texas statute under Lockett depends entirely on question number two in the statutory scliene, the sole vehicle by which the defendant can present a wide range of mitigatimg evidence to the sentencing jury. ${ }^{106}$ To repeat, question two asks "whether there is a probability that the defendant would commit criminal acts of violence that would constitute a continuing threat to society . . .."107 A brief examination of this question reveals that it does not permit the jury to fully perforn the task mandated for it by the "public attitudes" coinponent of the Supreine Court's death penalty jurisprudence. Whatever mitigating evidence the jury can hear under this question, the jurors are not free to determine whether the death sentence in an individual case is consistent with evolving standards of decency because the question only asks the jury to make a prediction about the defendant's future behavior. The question leaves little room, if any, for

105. Lockett v. Ohio, 438 U.S. at 625 (White, J., concurring) ("The value of capital punishment as a deterrent to those lacking a purpose to kill is extremely attenuated. Whatever questions may be raised concerning the efficacy of the death penalty as a deterrent to intentional murdersand that debate rages on-its function in deterring individuals from becoming involved in ventures in which death may unintentionally result is even more doubtful.").

106. See notes 53-65 and accompanying text supra.

107. Tex. Code Crim. Proc. AnN. art. 37.071(b) (Vernon Supp. 1980). 
the jury to consider the appropriateness of the death sentence for the individual defendant in light of its collective social and moral behefs.

Further, a more detailed inquiry into question two reveals that it does not permit the jury to make the determination about retribution and deterrence that the dignity of man element of the eighth aniendinent requires. This criticisin is not novel, ${ }^{108}$ but it takes on new meaning in the wake of Lockett.

By its terms, question two seeins directed at what has been terned specific deterrence or incapacitation-the goal of using a sentence to prevent the defendant from committing crimes in the future. ${ }^{109}$ In its analysis of the penological justifications for capital punishment, the 1976 plurality viewed this goal as hardly worthy of mention, presumably because the state can almost always incapacitate a murderer from future crimes by sentencing him to life imprisonment. ${ }^{110}$ But in focusing on incapacitation, question two fails to address retribution-society's noral outrage at the defendant's offense. The incapacitation goal of question two looks to the future, while retribution looks to the past. The inoral depravity of an offense depends on the nature of the criminal act and on the inanner of its commission: The nioral character of the offender will be reflected in his completed act. The question of whether the offender will commit future crimes inay involve a hazardous prediction of the morahty of his future behavior, but it has no relation to retribution for what he already has done. Accordingly, the mental illness of the defendant-classified as a mitigating factor under other state statutes, ${ }^{111}$ presuinably because a mentally impaired person, who may be unable to perceive the moral and practical consequences of his conduct and to control his actions, mvokes less moral outrage in society-has no mitigating effect under the Texas statute because mentally ill defendants may be more likely than others to commit violent acts in the future. Thus, the goal of specific deterrence underlying question two and the goal of retribution, which were considered by the 1976 plurality to justify for the death penalty, may point in opposite directions.

Question two of the Texas statute also does not address the penological goal of general deterrence-the punishment of one offender to prevent other people froin becoming offenders in the future. The plurahity in the 1976 Cases assumed that the death penalty will deter certain types of murderers, such as hired assassins and individuals already

108. See The Supreme Court, 1975 Term, 90 HARv. L, REv. at 71-72.

109. See H. PACKer, The Limits of THE Criminal SANCTION 45 (1968).

110. Gregg v. Georgia, 428 U.S. at 183 n.28; see note 22 supra.

111. See note 80 supra. 
serving life sentences, ${ }^{112}$ but will not deter someone who inurders in a moment of unthinking .passion. ${ }^{113}$ The plurahty's analysis, however, left open the question of how to identify those capital defendants whose execution is most likely to have the desired deterrent effect. A sensible answer is that a potential murderer will most likely be deterred by the execution of a murderer with whose character and action he can readily identify. ${ }^{14}$ Put another way, the most appropriate defendant to execute is one whom the death penalty is, as a general matter, most likely to deter. ${ }^{115}$ Question two of the Texas statute, however, is ill-suited to identifying such defendants. For example, among those most likely to continue to commit criminal acts of violence are defendants whose mental incapacity or flaws of character will continually prevent thein from appreciating the consequences of their acts. Yet, precisely because these defendants are unable to perceive the consequences of their acts, they are distinctly unlikely to be deterred.

Question two therefore does not allow the jury to determine whether the imposition of the death penalty in the particular case would serve the retributive or deterrent goals that alone can justifyconsistently with the dignity of man-the imposition of the death penalty. And because a Texas sentencing jury must consider proffered mitigating factors within the context of answering question two, it cannot give independent mitigating weight to factors that mitigate by disprovmg the retributional or deterrent value of a death sentence. The sentencing jury therefore may not be able to ensure that a death sentence for a particular defendant is consistent with the dignity of nuan.

Thus, like the Ohio law struck down in Lockett, the Texas statute prevents the sentencer from giving independent mitigatimg weight to any and all proffered aspects of character, record, and offense. The Texas statute precludes sentencer consideration of nnitigating circunstances and thereby fails to ensure that an individual death sentence comports with the requirements set out in the 1976 Cases for a constitutionally valid death sentence: consistency with evolving standards of decency and with the dignity of nuan.

\section{B. The Georgia Statute}

Georgia's present death penalty statute ${ }^{116}$ was enacted after Furman, and was sustamed by the Suprenie Court in Gregg v. Geor-

112. See Gregg v. Georgia, 428 U.S. at 185-86.

113. Id.

114. See Liebman \& Shepard, supra note 20 , at 813-17.

115. Id. at 814 n.257.

116. GA. CODE ANN. § 27-2534.1 (1978). 
gia. ${ }^{117}$ The statute allows the capital defendant to present any mitigating evidence, ${ }^{118}$ and allows the sentencing authority-which can be either judge or jury ${ }^{119}$ - to consider any proffered mitigating circumstance as an independent reason for mitigating the defendant's sentence. ${ }^{120}$ Indeed, the jury can exercise mercy and impose a noncapital sentence ${ }^{121}$ even if it has not found any mitigating circuinstances in the case. $^{122}$ The Georgia statute therefore appears to satisfy the substantive Lockett requirements that are the undoing of the Texas statute.

The statute, however, invites inquiry into another important implication of Lockett: the defendant's procedural right to the jury instructions necessary to give effect to the substantive Lockett requirements.

\section{The Georgia Law on Capital Sentencing Instructions}

The Georgia statute differs from the Texas law in that it explicitly deals with the subject of jury instructions. The Georgia law provides that in cases in which the sentencing authority is a jury, the trial court must mstruct the jury to consider any aggravating and mitigating cir-

117. 428 U.S. 153 (1976). In its recent decision in Godfrey v. Georgia, 100 S. Ct. 1759 (1980), however, the Court found that one of the statutory aggravating circumstances was unconstitutionally vague as construed and applied.

118. Collier v. State, 244 Ga. 553, 566-67, 261 S.E.2d 364, 375-76 (1979). The statute itself is silent as to the scope of the defendant's ability to present initigating evidence, but the state courts have construed it as conferring a broad right to introduce mitigating evidence. E.g., Cobb v. State, 244 Ga. 344, 357-59, 260 S.E.2d 60, 70-71 (1979); Brown v. State, 235 Ga. 644, 647-50, 220 S.E.2d 922, 925-27 (1975); see Gregg v. Georgia, 428 U.S. at 164, 203-04. The only restrictions on this right are the trial judge's traditional ability to limit cumulative testimony, Cobb v. State, 244 $\mathrm{Ga}$ at 359,260 S.E.2d at 71 , and the trial court's power to enforce evidentiary rules of relevancy or other admissibility requirements when the mitigating weight of the evidence fails to outweigh the harm resulting from the violation of the evidentiary rule, Collier v. State, $244 \mathrm{Ga}$. at 567, 261 S.E.2d at 376.

119. In the first phase of the bifurcated capital trial, the defendant's guilt or innocence is determined by either a jury or judge in the traditional manner. See GA. Code ANN. $\$ \S 26-3102$ (1977), 27-2503, 27-2528 (1978). In those cases in which the issue of guilt was tried to a jury, the jury also makes the capital sentencing determination. Id. $\$ 27-2503($ b). If the judge sat without a jury in the guilt phase, or if the defendant pleaded guilty, then the trial judge makes the sentencing determination. Id. $\$ \S 27-2503$ (a), 27-2528.

120. Gregg v. Georgia, 428 U.S. at 163-64, 197; Cobb v. State, 244 Ga. 344, 358-59, 260 S.E.2d 60, 71 (1979); GA. CODE ANN. § 27-2534.1(b) (1978) (judge or jury "shall consider . . . any unitigating circumstance"). As the state courts have observed, the statutory scheme empowers the seutencer to consider as "mitigating" anything it finds to be mitigating, without limitation or definition. Cobb v. State, 244 Ga. 344, 359, 260 S.E.2d 60, 71 (1979); Spivey v. State, 241 Ga. 477, 479,246 S.E. $2 d$ 288, 291 (1978).

121. The jury's decision is rendered in the form of a binding recommendation to the trial judge to exercise or not to exercise mercy. GA. CODE ANN. \& 27-2302 (1978).

122. Gregg v. Georgia, 428 U.S. at 197; Collier v. State, 244 Ga. 553, 569, 261 S.E.2d 364, 376 (1979); see GA. CODE ANN. $\$ 27-2302$ (1978); Towns v. State, 149 Ga. 613, 614-15, 101 S.E. 678, 679 (1919) (construing statute to apply to capital homicide offenses). The statute "leaves to the jury an unlimited power to recommend mercy with or without reason." Brawner v. State, $221 \mathrm{Ga}$. 680, 685, 146 S.E.2d 737, 741 (1966); Wyatt v. State, 220 Ga. 867, 869, 142 S.E.2d 810, 812 (1965). 
cumstances in the case and to consider specifically any of the ten statutorily enumerated aggravating circumstances that might apply. ${ }^{123}$ Thus, as the Georgia Supreme Court has recogmized, the capital defendant has a statutory right to an imstruction directing the jury to consider all mitigating circumstances in determining whether death is the appropriate punishment. ${ }^{124}$ However, the Georgia court has cautioned that the defendant is entitled to no more than a general imstruction regarding the sentencer's obligation to consider mitigating circumstances. The defendant can demand an instruction charging the jury to consider "all the evidence including any and all evidence of mitigating circumstances,"125 but does not have a right to an instruction that describes explicitly the particular mitigating circumstances in the case. ${ }^{126}$ This judicial construction of the statutory language has resulted in a striking difference in capital cases between the instructions that describe aggravatimg circumstances and those that describe mitigating circumstances. The statute requires the trial judge to recite those statutory aggravating factors whose presence is supported by the evidence, and to specifically direct the jury to consider the apphicability of those factors. Yet it does not require the judge to give imstructions that refer specifically to the particular mitigating circumstances that may be present in the case.

This contrast between the treatment of aggravating and mitigating circumstances is even more apparent in the written jury imstructions required under Georgia law. In addition to orally instructing the jury regarding the applicable legal standards, the trial judge must provide the jury in a capital case witl written mstructions for use during its deliberations. ${ }^{127}$ These written instructions reflect the format of the statute itself, and thus set forth each of the potentially applicable statutory aggravating circumstances while providing only a general direction to consider any mitigating circunistances that might apply. ${ }^{128}$

The Georgia statute thus raises two fundamental questions concerning mitigatimg circumstances and jury instructions: (1) Does a de-

123. "[T]he judge . . . shall include in his instructions to the jury for it to consider, any mitigating circunstances or aggravating circumstances otherwise authorized by law and any of the following statutory aggravating circumstances which may be supported by the evidence....." GA. CODE ANN. § 27-2534.1 (1978).

124. Burger v. State, 242 Ga. 28, 33, 247 S.E.2d 834, 838 (1978); Spraggins v. State, 240 Ga. $759,673,243$ S.E.2d 20, 23 (1978); Hawes v. State, 240 Ga. 327, 334, 240 S.E.2d 833, 839 (1977).

125. See, e.g., Collier v. State, 244 Ga. 553, 568-69, 261 S.E.2d 364, 376 (1979); Bowen v. State, 244 Ga. 495, 496-97, 260 S.E.2d 855, 856-57 (1979).

126. Bowen v. State, 244 Ga. 495, 497, 260 S.E.2d 855, 856-57 (1979); Redd v. State, 242 Ga. 876, 881-83, 252 S.E.2d 383, 387-88 (1979); Thomas v. State, 240 Ga. 393, 401, 242 S.E.2d 1, 7 (1977).

127. Ga. Code ANN. \$27-2534.1(c) (1978); see, e.g., Spraggins v. State, 243 Ga. 73, 75, 252 S.E.2d 620, 622 (1979).

128. See, e.g., Collier v. State, 244 Ga. 553, 569, 261 S.E.2d 364, 377 (1979). 
fendant have a constitutional right to receive jury instructions that specifically set forth the mitigating circumstances in the case?; and (2) assuming that defendants do not have a general constitutional right to such instructions, does the Georgia statutory requirement of particularized instructions on aggravating circumstances give Georgia defendants a corresponding right to specific instructions regarding mitigating circumstances? The Georgia Supreme Court's position on these issues is clear. In response to defendants' challenges to the statute, the Georgia court has repeatedly and consistently held that a defendant does not have an absolute right to itemization of mitigating circuinstances in jury instructions and does not gain such a right as a result of the statutory treatment of jury instructions regarding aggravating circumstances. ${ }^{129}$ To determine the validity of the Georgia court's analysis, we must again turn to the 1976 Death Penalty Cases and to Lockett.

\section{The Supreme Court's View of Capital Sentencing Instructions}

In the 1976 decisions, the plurality emphasized the importance of jury instructions as a ineans of satisfying the eighth ainendment requirement of rehability in capital sentencing. Explaining that sentencer awareness of comprehensive, accurate information about the defendant is essential to a rehable and individualized sentencing determination, ${ }^{130}$ the plurality observed that merely providing the jury with the evidence may not be sufficient, since jurors have hittle experience in sentencing and are unskilled in absorbing and applying sentencing information. ${ }^{131}$ The jury must therefore receive "guidance in its decisionmaking," particularly as to the types of factors that are relevant to the sentencing decision and the proper ineans for applying these factors to the determination of sentence. ${ }^{132}$ The plurality concluded that jury instructions are an indispensable mechanism for providing this type of guidance to a capital sentencing jury. ${ }^{133}$

Thus, as some commentators have observed, the 1976 decisions elevated the defendant's common law right to jury instructions on a proffered defense to an eighth amendment right to instructions regarding the mitigating circumstances in a capital case. ${ }^{134}$ The 1976 Cases, how-

129. E.g., id. at 568-69, 261 S.E.2d at 376-77; Bowen v. State, 244 Ga. $495,496-97,260$ S.E.2d 855, 856-57 (1979); Redd v. State, 242 Ga. 876, 881-83, 252 S.E.2d 383, $387-88$ (1979).

130. See Jurek v. Texas, 428 U.S. at 271; Gregg v. Georgia, 428 U.S. at 189-92.

131. Gregg v. Georgia, 428 U.S. at 192.

132. Id. at 192-93, 195.

133. Id. at 193-95.

134. Liebman \& Shepard, supra note 20 , at $786-88$. The authors note that the right to an instruction on mitigating circumstances also derives from the traditional right of the criminal defendant to obtain an instruction on any theory of the defense case, $i d$. at 786 , or on any constitutional defense, id. at 787, and that enforcement of this right also aids the appellate courts in their review of death sentences, which the 1976 Cases held to be an important feature of eonstitutional 
ever, left the scope of this right unclear. The plurality required at least a general instruction on mitigating circumstances, but did not explain whether the defendant could demand an itemization of the relevant mitigatimg circumstances in the jury instructions. The plurality's emphasis on "guidance regarding the factors about the crime and the defendant that the State, representing organized society, deems particularly relevant to the sentencing decision" 135 seems to call for specific reference to applicable mitigating circumstances as well as statutory aggravating circuinstances. Yet the Gregg plurality, in sustaining the Georgia scheme, did not inquire whether anything more than a general instruction on mitigating circumstances is necessary.

The Lockett decision lias implicitly answered this question. Lockett establishes that a death penalty statute must allow the capital sentencing authority to consider the independent mitigating weight of any and all aspects of character, record, and offense proffered by the defendant. Lockett thus placed a premium on the sentencer's ability to consider fully and effectively eacli such mitigating factor. The root of this concern is the practical need for reliability in the capital sentencing judgment. The Court emphasized that " $[t]$ he nonavailability of corrective or modifying mechanisms with respect to an executed capital sentence" ${ }^{136}$ necessitates reliability in the decision to impose death. And, the Court explained,

a statute that prevents the sentencer in all capital cases from giving independent mitigating weight to aspects of the defendant's character and record and to circumstances of the offense proffered in mitigation creates the risk that the death penalty will be imposed in spite of factors which may call for a less severe penalty. When the choice is between life and death, that risk is unacceptable and incompatible with the commands of the Eighth and Fourteenth Amendments. ${ }^{137}$

Thus, the eighth anendment's concern for reducing the risk of an inappropriate death sentence requires that the sentencer be able to consider all of the "factors which niay call for a less severe penalty."

This practical constitutional concern for sentencer awareness and consideration of all mitigating factors brings us inescapably back to jury instructions. As the plurality recognized in the 1976 decisions, jury instructions are an indispensable device for ensuring that the jury understands and considers the legal effect of the evidence that it has

death penalty procedures, id. at $788 \mathrm{n} .127$. The authors add that when the prosecution offers purportedly aggravating evidence, the defense must be allowed an instruction on the potentially mitigating weight of that same evidence. Id. at 788 n.126.

135. Gregg v. Georgia, 428 U.S. at 192.

136. 438 U.S. at 605 .

137. Id 
heard. ${ }^{138}$ Absent an itemized instruction, the jury might perceive the mitigating evidence as an inchoate collection of information and arguinent. For exainple, a jury that has heard mitigatimg evidence concerning the defendant's age and emotional disturbance may fail to understand that it can consider each of these factors as an independent basis for mitigating sentence. An express instruction informing the jury of the mitigatimg circumstances proffered by the defense enables the jury to appreciate the defense's legal theory of mitigation as well as to receive its mitigating evidence. Without an itemized instruction, the average jury may be unable to extrapolate from the mass of mitigating evidence presented the mitigating circumstances that, in the defense's view, provide independent and sufficient grounds for rejecting the death penalty. The uninstructed jury may be unable to consider the mitigating factors in the sense intended by Lockett. ${ }^{139}$

A capital defendant thus has an implicit right to an itemization of mitigating circumstances in jury instructions to ensure that the jury can consider the mitigating weight of eacli of the proffered aspects of character, record, and offense. ${ }^{140}$ The Georgia statute therefore violates Lockett and the eighth amendment reliability requirement. By restrictimg the oral and written jury instructions to a general directive to consider the mitigating circumstances in the case, the Georgia statute prevents the jury from receiving the guidance that it needs in order to consider fully the independent mitigating weight of all proffered aspects of character, record, and offense.

\section{The Reciprocal Right to Jury Instructions}

A second defect in the Georgia statutory procedure for jury instructions in death penalty cases is that the procedure expressly enu-

138. See notes 130-33 and accompanying text supra.

139. The need to inform the jury of the mitigating circumstances of the case cannot be satisfied by defense counsel's description of the proffered mitigating evidence in closing argument. As the Supreme Court observed in another context, "arguments of counsel cannot substitute for instructions by the court." Taylor v. Kentucky, 436 U.S. 478, 488-89 (1978) (concluding that the trial court's erroneous omission of a jury instruction on the presumption of innocence was not remedied by defense counsel's explanation of the presumption in opening and closing arguments). An instruction is necessary to invest the particular concept with the authority of the trial court. See id. at 489.

140. See Chenault v. Stynchcombe, 581 F.2d 444, 448 (5th Cir. 1978) (Lockett "mandate[s] that the judge clearly instruct the jury about mitigating circumstances," since the "constitutional requirement to allow consideration of mitigating circumstances would have no importance, of course, if the sentencing jury is unaware of what it may consider in reaching its decision"); $c f$. State v. Johnson, 298 N.C. 47, 74, 257 S.E.2d 597, 616-17 (1979) (Lockett holding precludes instructing on only some mitigating circumstances and leaving others to the jury's recollection). But see Clark v. Commonwealth, 220 Va. 201, -, 257 S.E.2d 784, 791 (1979), ccr. denied, 100 S. Ct. 741 (1980) (concluding that Locketr does not require itemization of mitigating circumstances in jury instructions). 
merates aggravating circumstances without according the same treatment to mitigating factors. ${ }^{141}$ Even if there were no constitutional right to enumeration of all mitigating factors in jury imstructions, this disparity between the statute's treatment of aggravatimg circumstances and its treatment of mitigating circumstances is itself sufficient reason why the Georgia statute is unconstitutional.

Express reference to a particular fact or issue in a jury instruction has several effects. First, the reference enables the jurors to remember more clearly the factors described in the instruction. Second, it describes the legal theory of the party that introduced the evidence and explains the way in which the evidence presented supports this theory. Third, the trial judge's explicit reference to the party's legal theory cloaks that theory in the autliority and credibility of the judge. ${ }^{142}$

All of these effects occur when a Georgia trial judge instructs a capital sentencing jury that it can consider prosecutorial evidence of, for example, the defendant's substantial record of prior assaultive crimes $^{143}$ or the commission of the murder for the specific purpose of avoiding arrest ${ }^{144}$ as aggravating circumstances. The instruction helps the jury to recall the evidence and, more important, informs it that these factors can have the legal effect of aggravatimg sentence and weighing in favor of death. Finally, the instruction adds the force of the judge's wisdom and authority to the proposition that these factors weigh im favor of death.

In contrast to the charge on aggravating circumstances, the imitigation instruction merely directs the jury to consider the mitigating circumstances in the case, without specifically delineating tle mitigating effect of the particular aspects of character, record, or offense proffered by the defendant. Thus, the jury is given no specific reminder of the defendant's evidence of, for example, his or her youtl or einotional disturbance. Nor is the jury informed that these particular factors can have a mitigating effect. ${ }^{145}$ And, of course, the judge does not lend his personal authority to the proposition that these factors weigh in favor of lemiency.

141. Mulligan v. State, 245 Ga. 266, 264 S.E.2d 204 (1980); Collier v. State, 244 Ga. 553, 569, 261 S.E.2d 364, 377 (1979).

142. See, e.g., Quercia v. United States, 289 U.S. 466, 470-72 (1933) ("The influence of the trial judge on the jury 'is necessarily and properly of great weight' and 'his lightest word or intimation is received with deference, and nay prove controlling' "; trial judge's statement to jury that " 'wiping' one's hands while testifying [as the defendant had done] was 'almost always an indication of lying" " served to impermissibly pit the judge's "own experience, with all the weight that could be attached to it, in the scale against the accused"); United States v. Cisneros, 491 F.2d 1068, 1072-76 (5th Cir. 1974).

143. Ga. Code ANN. § 27-2534.1(b)(1) (1978).

144. Id. \& 27-2534.1(b)(10).

145. See notes 126, 128 and accoinpanying text supra. 
The submission to the jury of a written version of the statutory instructions for use during its dehiberations magnifies the inequality in the treatment of aggravating and mitigating circumstances. Whenever a jury has a written version or summary of evidence to use in its deliberations, that evidence assumes particular importance and weight. ${ }^{146}$ Thus, when the jury receives and takes into the jury room a written form that lists aggravating factors but not mitigating factors, it tends to give the aggravating circumstances singular emphasis. ${ }^{147}$

The Georgia procedure for jury instructions, with its disproportionate einphasis on aggravating circumstances, is inconsistent with the due process clause of the fourteenth amendment, which stands as the ultimate guarantor of "the balance of forces between the accused and his accuser," and prohibits the state from furnishing "nonreciprocal benefits to the [prosecution] . . . when the lack of reciprocity imterferes with the defendant's ability to obtain a fair trial." 148 Similar common law principles require a trial judge to be fair and evenhanded in his comments on the evidence ${ }^{149}$ and in his charge to the jury at the close of a case. ${ }^{150}$

Thus, when a Georgia trial judge highlights and reinforces the prosecution's aggravating evidence without according the defendant's

146. C. MCCoRMick, HANDBOOK ON EvidenCE $\$ 217$, at 540 (2d ed. 1972). This phenomenon is the root of the special evidentiary rules for documentary exhibits in the jury room and juror notetaking. Id. at $540 \&$ n.30. See, e.g., Gallagher v. Viking Supply Corp., 3 Ariz. App. 55, 60, 411 P.2d 814, 819 (1966) (documentary exhibits); Fisher v. Strader, 399 Pa. 222, 225, 160 A.2d 203, 204 (1960) (juror notetaking); FED. R. Evid. 803(5), (18).

147. Cf. State v. Johnson, 298 N.C. 47, 70-74, 257 S.E.2d 597, 614-17 (1979) (written form that jury takes into the jury room, and that lists statutory but not nonstatutory mitigatimg circumstances, gives disproportionate emphasis to the mitigating circumstances printed on the form even when oral instructions describe all the mitigating evidence in the case). In several noncapital cases, courts have recognized that the practice of writing down and sending only part of the oral instructions to the jury creates the danger of the jury overemphasizing the written matters. See, e.g., People v. Wingo, 34 Cal. App. 3d 974, 984, 110 Cal. Rptr. 448, 454 (Ist Dist. 1973); Commonwealth v. Baker, $466 \mathrm{~Pa}$. 382, 395-98, 353 A.2d 406, 413-14 (1976).

148. Wardius v. Oregon, 412 U.S. 470, 474-75 \& n.6 (1973). The Court observed in Wardius that the constitutional requirement of reciprocity of procedural benefits was also at the heart of earlier holdings that a criminal defendant lias a right to counsel at public expense, Gideon v. Wainwright, 372 U.S. 335 (1963), and that a state statute cannot bar defense presentation of a codefendant's testimony while simultaneously permitting the co-defendant to testify for the prosecution, Washington v. Texas, 388 U.S. 14, 16-17, $22-23$ (1967). See Wardius v. Oregon, 412 U.S. at 474 n.6.

The due process requirements established in Wardius, like other due process requirements, apply fully to the capital sentencing phase of a trial. See Presnell v. Georgia, 439 U.S. 14 (1978) (per curiam); Gardner v. Florida, 430 U.S. 349 (1977).

149. See, e.g., Quercia v. United States, 289 U.S. 466, $469-71$ (1933) (establishing this limitation on the federal common law principle permitting the trial judge to comment on the evidence); State v. Marshall, 105 R.I. 288, 293-95, 251 A.2d 541, 544-45 (1969); C. MCCoRMICK, supra note $146, \S 8$, at $12-13$.

150. See Speers v. United States, 387 F.2d 698, 702 (10th Cir. 1967), cert. denied, 391 U.S. 956 (1968). 
mitigating evidence similar treatinent, he disrupts the balance between the parties and impermissibly furnishes a nonreciprocal benefit to the prosecution on a inatter that is crucial to a fair determination of sentence. ${ }^{151}$

The Lockett decision demonstrates that the eighth amendment also requires equality of treatment in jury instructions in a capital sentencing hearing. The Court held in Lockett that a capital sentencing authority must be permitted to give full consideration to eacli and every mitigating circumstance. When a procedure for giving jury instructions reduces the importance of any of the proffered mitigating circumstances $m$ the minds of the jurors, it unconstitutionally precludes those factors from receiving effective sentencer consideration. ${ }^{152}$ The Georgia procedure has precisely this effect. Aggravating and mitigating circumstances stand on a balance in eacli case, and must be weighed against each other by the jury. The oral and written jury instructions einphasize and reinforce only the aggravating circumstances, and thus add weight to the aggravating side of the balance.

Iromically, under the Georgia statute the prosecutor enjoys a "Lockett right" to have the jury give independent mitigatmg weight to the aggravating circumstances that it proffers. The jury not only hears the aggravating evidence, but also is instructed in the prosecution's legal theory of the appropriateness of a death sentence when the judge explains the actual aggravating circumstances that the jury may infer from the evidence. By contrast, the defense can only present its mitigating evidence and hope that the jury, unaided by the judge, will be able to perceive the defense's legal theory as to which circumstances argue for mitigation. ${ }^{153}$

The Georgia statutory procedure for jury instructions therefore violates Lockett in two respects. Because the trial court does not enuinerate mitigating circuunstances in the jury instructions, the jury lacks the guidance that it needs to consider fully the proffered mitigating factors. Furthernore, the itemization of aggravating circumstances without equivalent treatınent of mitigating circumstances results in a disproportionate einphasis on the aggravatimg factors and a corresponding decrease in the effectiveness of the sentencer's consideration of mitigating circumstances.

151. Wardius v. Oregon, 412 U.S. 470, 474 (1973). As the Court implicitly acknowledged in Wardius, the proper balance between defense and prosecution is not a precisely equal balance but, rather, is weighted against the prosecution in order to guard against erroneous convictions of innocent persons. See id. (citing the discussion of the beyond a reasonable doubt standard in In re Winship, 397 U.S. 358, 361-64 (1970)).

152. See State v. Johnson, 298 N.C. 47, 70-74, 257 S.E.2d 597, 614-17 (1979).

153. See text accompanying notes 138-39 supra. 


\section{III \\ APPLYING LOCKETT: A PRIMER OF LOCKETT \\ REQUIREMENTS}

\section{A. Applying Lockett to Statutes}

\section{General Approach}

In determining whether a state death penalty statute satisfies the eighth amendment requirements established im Lockett $v$. Ohio, a court should employ a two-stage approach. The court should first examine the mitigatmg circumstances provision of the statute. If it unequivocally estabhishes an exclusive roster of mitigating circunstances, the statute operates im essentially the same manner as the Ohio law struck down in Lockett, and the court must invalidate it. ${ }^{154}$ If the state statute survives this first test, then the reviewing court unust also consider .whether the statute complies with the substantive and procedural requirements implicit in the Lockett decision: (1) The statute must permit the sentencer to treat any proffered mitigating factor as a reason in and of itself for exercising leniency and imposing a noncapital sentence; and (2) it must provide any procedures necessary to enable the sentencer to consider effectively each of the factors that may call for a less severe penalty.

Our discussion of the Texas statute demonstrated the means for applying the first requirement, which is grounded in the Lockett principle of mdependent mitigating weight. ${ }^{155}$ The reviewing court should determine whether the statutory structure for capital sentencing precludes the sentencer from treating each proffered factor as a reason for finding that leniency is appropriate or that a death sentence would not serve the ends of retribution or deterrence.

Our review of the Georgia death penalty statute illustrated the procedural safeguards required by Lockett. The reviewing court should consider whether the statute permits the use of proceduressuch as the itemization of mitigating factors in jury instructions precluded in Georgia - that are necessary to enable the sentencer to consider effectively the proffered mitigating circumstances. If such procedural safeguards are unavailable, the statute does not meet the constitutional standards imposed in Lockett.

In applying these requirements to a new statute, the court might usefully compare the statutory scheme in question with other laws that have already been found constitutional or unconstitutional. ${ }^{156}$ The key

154. See, e.g., State v, Watson, 120 Ariz. 441, 444-45, 586 P.2d 1253, 1256-57 (1978), cerf. denied, 440 U.S. 924 (1979).

155. See notes 78-115 and accompanying text supra.

156. The Oregon statute, for example, can be seen to violate Lockeft because it employs virtu- 
to Lockett analysis, however, remains the identification and application of the general Lockett principles, which transcend any particular statutory scheme. The lower courts have failed to appreciate many of the intricacies of the Lockett holding because they simply have compared the challenged statutes with the Ohio law without considering the general constitutional concerns that resulted in the invalidation of the Ohio statute. The Lockett decision is certainly a difficult case to work with, since the Supreme Court did not identify explicitly the principles that it was applying to the Ohio law. However, as this discussion has deinonstrated, close study of the decision and its factual context inakes it possible to apply Lockett to other statutes.

\section{The Problem of State Court Evasion of Lockett Challenges to Statutes: The Example of the Florida Death Penalty Statute}

The application of Lockett to state statutes has proven particularly troublesome in states in which state courts have construed death penalty statutes in such a way as to evade the effect of Lockett. In these states, courts have ignored statutory language and earlier case law to construe apparently exclusive statutory rosters as nonexclusive and have then applied the new constructions retroactively to validate sentences imposed under the previous, unconstitutional constructions of the statutes. ${ }^{157}$ In such states, the application of Lockett to the state statute inust include a preliminary determination of the validity of the state court's use of its statutory construction powers to defeat the federal constitutional right established in Lockett. The following study of the application of Lockett requirements to the Florida death penalty statute suggests a way to resolve this preliminary question.

\section{a. The Florida Statutory Standard: A Strange History in Three Phases}

The modern Florida death penalty statute was enacted in 1972, in the wake of the Furman decision. ${ }^{158}$ Under the statute as origmally

ally the same structure for capital sentencing as does the Texas law. Compare OR. REv. Stat. \$ 163.116 (1979) with Tex. CrIM. Pro. CODE ANN. art. 37.071 (Vernou Supp. 1980). Similarly, the Delaware and Virginia statutes violate Locketl because they suffer from the same defect as the Georgia law: They preclude specific reference to proffered mitigating circumstances in the jury instructions. Compare DEL. CODE ANN. tit. 11, §4209(c)(4) (1979), and VA. CODE $\S 19.2-$ 264.4(D) (Supp. 1979) with GA. CodE ANN. § 27-2534.1 (1978).

157. The textual discussiou in this sectiou focuses on the Florida Supreme Court's adoption of such a construction. For a discussion of similar actions by other state supreme courts, see note 203 infra.

158. 1972 Fla. Laws ch. $72-724, \S 9$ (codified at FlA. Stat. ANN. $\$ 921.141$ (West Supp. 1980)). 
enacted, ${ }^{159}$ the parties to a capital sentencing hearing could present evidence "as to any matter that the court deems relevant to sentence." 160 At the conclusion of the hearing, the sentencing jury had to decide whether mitigating circumstances outweighed aggravating circumstances and whether, as a result of this balance of aggravatimg and mitigating factors, the defendant should be sentenced to hfe imprisonment or death. ${ }^{161}$ The jury's determination was advisory only. Notwithstanding the recommendation of the jury, the trial judge then had to weigh aggravating and mitigating circumstances independently and decide whether the defendant should be sentenced to death. ${ }^{162}$ However, in those cases $m$ which the jury recommended a noncapital sentence, the trial judge could impose a death sentence only if "the facts suggesting a sentence of death [were] so clear and convincing that virtually no reasonable person could differ." 163

The Florida statute listed eight aggravating circumstances ${ }^{164}$ and seven mitigatimg circumstances. ${ }^{165}$ The statute expressly declared that aggravating circumstances in a capital sentencing proceeding were limited to the statutorily defined factors. ${ }^{166}$ In soinewhat less precise language, the statute then provided that the enumerated mitigatimg factors "shall be" mitigating circuinstances. ${ }^{167}$ Thus, although the statute indisputably limited aggravating factors to those enumerated, it was ambiguous as to whether mitigating circumstances were similarly restricted.

In the years following the statute's enactment, the Florida

159. The text refers to the original version of the Florida statute rather than to the current amended form, because the relevant federal and state case law all concerns the original version. However, most of the provisions of the statute have remamed unchanged simce their enactment. When the provision referred to in the text is one that has not been amended, the footnote will simply cite to the current statute for convenient reference. When the textual discussion refers to a provision that has been altered by later amendments, the footnote will cite to the original enactment and point out the changes worked by the amendment.

160. 1972 Fla. Laws ch. 72-724, §9. This provision was amended in 1979 and now provides that "evidence may be presented as to any matter that the court deems relevant to the nature of the crime and the character of the defendant." FLA. STAT. ANN. $§ 921.141$ (1) (West Supp. 1980). Both the original and the current versions specify that the evidence that can be presented specifically includes all evidence relating to the aggravating and mitigating circumstances enuinerated in the statute. Id; 1972 Fla. Laws ch. 72-724, $§ 9$.

161. Fla. STAT. ANN. $\$ 921.141(2)$ (West Supp. 1980).

162. Id. $\S 921.141(3)$.

163. Tedder v. State, 322 So. 2d 908, 910 (Fla. 1975); see Buckrem v. State, 355 So. 2d 111, 113-14 (Fla. 1978).

164. Fla. Stat. ANN. § 921.141(5) (West Supp. 1980) (current version includes ninth aggravating circumstance).

165. Id. $\S 921.141(6)$.

166. The statute states that "[a]ggravating circumstances shall be limited to the following [factors]," and then lists eight factors. Id. §921.141(5).

167. Id. $\$ 921.141(6)$. 
Supreme Court indicated repeatedly that it construed the mitigating circumstances provision as exclusive. At times the court's construction was implicit in its decisions. ${ }^{168}$ At other times it was explicit, approving in one case the decision of a capital sentencing judge who considered only the mitigating circuunstances "itemized" in the statute. ${ }^{169}$ And in conducting an mdependent review of the evidence in another capital case, the court concluded that no mitigating circuinstances existed in the case because all of the "statutorily enumerated circumstances" were inapplicable. ${ }^{170}$

In 1976, the Supreme Court in Proffitt v. Florida ${ }^{171}$ examined the Florida statute and concluded that it satisfied eighth amendment requirements by guiding the discretion of the sentencing authorities through its provisions for balancing aggravating and mitigating circumstances. ${ }^{172}$ In the course of reviewing the statute, the Proffit plurality suggested that the mitigatimg circumstances provision in the statute was open-ended, ${ }^{173}$ mexplicably ignoring the state case law demonstratimg that in fact the opposite was true. ${ }^{174}$

One week after the announcement of the Proffitt decision, the Florida Supreme Court explicitly declared in State v. Cooper ${ }^{175}$ that the Florida statute restricted mitigating factors to those set fortl in the statute. ${ }^{176}$ The court observed that the statutory language demonstrated a clear legislative intent to restrict mitigating circumstances to the statutorily enumerated factors. ${ }^{177}$

Since state courts are in most cases the final authority on the proper interpretation of a state statute, ${ }^{178}$ the Cooper decision seemed to settle the meaning of the Florida mitigating circumstances stan-

168. See, e.g., Alford v. State, 307 So. 2d 433, 444 (Fla. 1975), cert. denied, 428 U.S. 912 (1976) (statute "propound[s] . . . [the] aggravating and mitigating circumstances which inust be determinative of the sentence imposed"); State v. Dixon, 283 So. 2d 1, 9 (Fla. 1973) ("when one or more of the aggravating circumstances is found, death is presumed to be the proper sentence unless it or they are overriden by one or more of the mitigating circumstances provided in Fla. Stat. \$921.141(7), F.S.A.").

169. See Henry v. State, 328 So. 2d 430, 431-32 (Fla.), cert. denied, 429 U.S. 951 (1976).

170. Songer v. State, 322 So. $2 d$ 481, 484 (Fla. 1975), vacated on other grounds, 430 U.S. 952 (1977), on remand, 365 So. 2d 696 (Fla. 1978), cert. denied, 441 U.S. 956 (1979).

171. 428 U.S. 242 (1976).

172. Id at 252-53. The Court approved the statutory procedures "on their face" and not as actually applied. See note 24 supra.

173. See 428 U.S. at $250 \mathrm{n} .8$.

174. See notes $168-70$ and accompanying text supra.

175. 336 So. 2d 1133 (Fla. 1976), cert, denied, 431 U.S. 925 (1977).

176. 336 So. $2 d$ at $1139 \&$ n.7.

177. The court emphasized that the statute directed the jury and the trial judge to consider mitigating circumstances "as enumerated in" the statutory list. Id at 1139 n.7. The court observed that these are words of "mandatory limitation," id, and concluded that the legislature intended to establish a nonexpandable list of mitigating circumstances. Id at 1139.

178. See notes $187-89$ and accompanying text infra. 
dard-explicitly reaffirming the state courts' implicit construction of the mitigatimg circumstances provision as exclusive. It appeared, therefore, that the Umited States Supreme Court had incorrectly assuned in Proffit that under Florida law the statutory list was nonexclusive.

In the two years following the Cooper decision, the Florida Supreme Court adhered to its construction of the mitigatimg circumstances provision as exclusive. ${ }^{179}$ Then, in 1978, the state supreme court in Songer $v$. State ${ }^{180}$ abruptly reversed its position and repudiated its earlier construction of the statutory provision. The Songer case arose after Lockett, and the defendant in Songer, pointing out that the Florida Supreme Court's earlier decision in Cooper had stated explicitly that mitigatimg circumstances were limited to the factors enumerated im the statute, claimed that the Florida statute therefore violated Lockett by restrictimg sentencer consideration of mitigating circuinstances to the statutorily enumerated factors. The Florida Supreme Court responded by declaring that all of its earlier decisions, including Cooper, had consistently interpreted the death penalty statute as creatmg a nonexclusive set of mitigatimg circumstances. ${ }^{181}$ The court explained that its earlier decision in Cooper could not and should not be read as limitmg mitigatimg circumstances but merely as affirming the trial judge's customary right to exclude irrelevant evidence. ${ }^{182}$ The court then explicitly construed the mitigating circumstances provision as nonexclusive, and explained that the language of the statute reflected a legislative imtent to permit the sentencer to consider any mitigating circumstances proffered by the defendant. ${ }^{183}$ The Songer court accordingly rejected the defendant's claim that the death penalty statute unconstitutionally restricted mitigating circumstances to the factors identified in the statute. ${ }^{184}$

179. See, e.g., Gibson v. State, 351 So. 2 d $948,951 \&$ n.6 (Fla. 1977) (determining whether mitigating circumstances were present by examining the applicability of the statutorily enumerated mitigatory factors); Barclay v. State, 343 So. 2d 1266, 1270-71 (Fla. 1977) (approvingly noting that the trial judge had histed eacli statutory mitigating circumstance and had considered its applicabihity).

180. 365 So. 2d 696, 700 (Fla. 1978) (on rehearing), cert. denied, 441 U.S. 956 (1979).

181. 365 So. $2 \mathrm{~d}$ at 700 .

182. Id.

183. See id at $700 \&$ n.l. The court pointed out that the statutory hist of aggravating circumstances provides that "[a]ggravatimg circumstances shall be limited" to the factors in the list, whereas the statutory roster of mitigating circumstances merely provides that "initigating circunstances shall be" the factors in the roster. The court concluded that this nonparallel structure evidences a legislative imtent to render the list of mitigating circumstances nonexclusive, while restricting aggravating circumstances to the statutorily enumerated factors. Id. see Proffitt v. Florida, 428 U.S. at 250 n.8. For a discussion of the errors in the Songer court's evaluation of legislative intent, see note 199 and accompanyimg text infra.

184. The defendant in Songer was sentenced in 1977, see 365 So. 2d at $699 \mathrm{n.2}$, and the Florida Supreme Court's earher decision in Cooper v. State was controlling at that time. Thus, to reject Songer's claim that the statutory standard under whicl he was sentenced was unconstitu- 
Several months after the Songer decision, the Florida legislature amended the death penalty statute and deleted the language upon which the Cooper court had relied in concluding that mitigating circumstances were restricted to the statutorily defined factors. ${ }^{185}$ These amendments thereby demonstrated a new legislative intent to provide that mitigating circumstances are not restricted to the statutorily enumerated factors.

The history of post-Furman capital sentencing in Florida thus falls into three distmct periods: (1) Froin the enactment of the post-Furman statute in 1972 until the decision in Songer in December 1978, the Florida courts interpreted and applied the mitigating circumstances provision of the statute in a inanner that appeared exclusive, but lias subsequently been described by the Florida Supreme Court as nonexclusive; (2) from the Songer decision in December 1978 until the statutory amendments took effect in July 1979, the courts applied the mitigatimg circumstances provision as required by the Songer construction of the statute; and (3) beginning in July 1979, the mitigating circumstances provision itself specified that the statutory list of mitigating circumstances is nonexclusive.

The following discussion of the Florida statute will focus on the first of these three periods and examine the mitigating circuunstances standard that governed capital sentencing hearings during the years 1972-1978. Consideration of this standard is a means of addressing the problem of state courts re-construing statutes to evade Lockett claims. ${ }^{186}$

i. Reviewability of the Florida Supreme Court's interpretation of state law in Songer. The Florida Supreme Court stated in Songer that

tional, the Florida Supreine Court had to reinterpret the Cooper decision and other earlier case law. This would appear to explain why the Songer court not only re-construed the mitigating circumstances provision of the statute, but also reinterpreted the earlier case law that had construed the statute.

185. 1979 Fla. Law ch. 79-353. The Cooper court based its conclusions about legislative intent on the statutory language specifying that the jury and trial judge inust consider mitigating circumstances "as enumerated in" the list of mitigating factors. See note 177 supra. The 1979 amendments deleted the words "as enumerated in" from both the provisions governing the capital sentencing jury and the sentencing judge. See 1979 Fla. Law ch. 79-353, at sec. 1, $\S \S 921.141(2)(b),(3)(b)$. The Florida statute now provides simply that the jury and judge in a capital sentencing proceeding sliall consider the mitigating circumstances in the case. Id.

186. Although this mitigating circumstances standard was subsequently revised by judicial construction in the 1978 Songer decision and by legislative action in 1979, the constitutionality of the standard is hardly noot or of interest solely for analysis of the Lockett decision. All capital defendants who were sentenced to death in the years between the enactment of the statute in 1972 and the Songer decision in 1978 were sentenced in accordance with this earlier standard, and the constitutionality of these defendants' death sentences turns on the constitutionality of that standard. 
its earlier cases had construed and applied the mitigating circumstances provision as nonexclusive throughout the years 1972-1978. The Songer decision, as the most recent pronounceinent of the state's highest court, is binding on all Florida state courts, whether it is erroneous or not. As a matter both of comity and of jurisdiction, a federal court cannot review judgments of state courts on matters of state law, ${ }^{187}$ and a state court decision resting on adequate and independent state grounds cannot be reviewed in federal court even though it also involves a federal claim. ${ }^{188}$ A special exception to this doctrine exists, however, for state court decisions so lacking in "fair or substantial support" in state law as to be subterfuges or pretexts for evading a federal clain. ${ }^{189}$ The Songer case appears to fall within this exception, and so should not bar independent federal court construction of the Florida death penalty statute.

The Songer court based its conclusions about the mitigating circumstances standard einployed in earlier cases on a review of seven of its earher decisions. ${ }^{190}$ Citing these decisions, the court explained that it had repeatedly approved a trial court's consideration of initigating circumstances that were not included in the statutory list. ${ }^{191}$ Thus, the court concluded, the mitigating circuinstances provision of the statute had been consistently construed as nonexclusive. The court distinguished its earlier holding in Cooper $v$. State by declaring that the Cooper decision was concerned not with sentencer consideration of nonenumerated mitigating factors, but rather with the probative nature of particular mitigating evidence presented in the Cooper sentencing hearing. ${ }^{192}$

The case law cited by the Songer court, lowever, contradicts the

187. See Henry v. Mississippi, 379 U.S. 443, $446-47$ (1965). See generally P. BAToR, P. Mishkin, D. Shapiro \& H. Wechsler, Hart \& Wechsler's The Federal Courts and the Federal System 470-526 (2d ed. 1973).

188. Fox Film Corp. v. Muller, 296 U.S. 207, 210-11 (1935).

189. Mullaney v. Wilbur, 421 U.S. 684, 691 n.11 (1975); Radio Station WOW, Inc. v. Johnson, 326 U.S. 120, 129 (1945). Although the basis for this exception lies in the notion that state courts may intentionally misimterpret their own laws as an intentional subterfuge in order to avoid federal review, 326 U.S. at 129, the federal claimant need not surmount the difficult barrier of proving the state's actual intent to subvert federal jurisdiction. Rather, the test appears to be objective: The federal court can infer an intent to subvert federal jurisdiction where the state court application or construction of state law lacks "fair or substantial" support in state law. Lawrence v. State Tax Comm'r, 286 U.S. 276, 282 (1932); Broad River Power Co. v. South Carolina, 281 U.S. 537, 540 (1930).

190. See note 194 infra.

191. 365 So. $2 d$ at 700 .

192. Id. For a discussion of the discrepancy between this characterization of Cooper and the actual holding in Cooper, see note 196 and accompanying text infra. 
court's conclusions. ${ }^{193}$ In each of the decisions cited in the Songer opinion, the initigating circumstances that the trial judge and jury had considered were factors enumerated in the statute. ${ }^{194}$ Thus, contrary to the Florida court's assertions in Songer, its decisions in these cases had not "approved a trial court's consideration of circumstances in mitigation which are not included in the statutory list."195 Moreover, any fair reading of the Florida Supreme Court's earlier decision in Cooper reveals that this decision construed the initigating circumstances provision as exclusive. ${ }^{196}$

193. Since the Songer court purported to base its conclusions concerning the operation of the statute on earlier case law rather than on the wording or legislative history of the statute, our analysis of the fairness of the support for the court's holding also focuses on the earlier case law. Neither the wording nor the legislative history of the statute, however, would liave provided fair and substantial support for the Songer court's conclusion. See notes 197-99 and accompanymg text infra.

194. See Washington v. State, 362 So. 2d 658, 663-64 (Fla. 1978) (trial court found no mitigating circumstances because each of the factors enumerated in FLA. STAT. § 921.141(6) were inapplicable); Buckrein v. State, 355 So. 2d 111, 113 (Fla. 1978) (sole mitigating factor was absence of significant history of prior criminal activity, a factor designated a statutory mitigating circumstance in Fla. STAT. \$ 921.141(6)(a)); McCaskill v. State, 344 So. 2d 1276, 1277-78 (Fla. 1977) (possible mitigating circumstance, under FLA. STAT. $\$ 921.141(6)(d)$, was that defendant may have been merely an accoinplice in a capital felony committed by another person); Chambers v. State, 339 So. 2d 204, 205 (Fla. 1976) (trial court considered but found inapplicable defendant's claimed mitigating circumstances, under FLA. STAT. $\$ 921.141(6)(b)$, of influence of mental or emotional disturbance); Meeks v. State, 336 So. 2d 1141, 1143 (Fla. 1976) (trial court considered mitigating circumstances of defendant's age, FLA. STAT. $\$ 921.141(6)(\mathrm{g})$, and impaired mental capacity, FLA. STAT. § 921.141(6)(b), (f)); Messer v. State, 330 So. 2d 137, 141-42 (Fla. 1976) (possible mitigating circumstances were the degree of the defendant's participation in the capital felony, FLA. STAT. $\$ 921.141(6)(d)$, and the influence of mental or emotional disturbance, FLA. STAT. $\S 921.141(6)(b)$ ); Halliwell v. State, 323 So. 2d 557, 561 (Fla. 1975) (mitigating circumstances were absence of significant history of prior criminal activity, FLA. STAT. $\$ 921.141(6)(a)$, and influence of extreme emotional disturbance, Fla. STAT. \$921.141(6)(b)). In Buckrem and Halliwell, the Florida Supreme Court's description of mitigating evidence included nonstatutory factors, but these factors were not relied on by the trial courts in their consideration of mitigating circumstances.

195. Songer v. State, 365 So. $2 d$ at 700 . The possibility of considering nonenumerated factors was never mentioned in six of the seven decisions cited by the Songer court. In the seventh opmion, Washington $v$. State, the defendant raised the claim that the trial court had erred in failing to consider the nonstatutory mitigating circumstance that he voluntarily surrendered to the authorities and had confessed and ultimately pleaded guilty to all charges. 362 So. 2d 658, 667 (Fla. 1978). The trial judge in Washington had considered only statutory mitigating circumstances. See id. at 663-64. The Florida Supreme Court rejected the defendant's claim and commented that "[w]hile we do not foreclose consideration of such factors in mitigation in an appropriate case, we do not believe the appellant's actious are compelling liere." Id at 667. Thus, the Washington decision also did not "approve . . . a trial court's consideration of circumstances in mitigation which are not included in the statutory list." Songer v. State, 365 So. $2 \mathrm{~d}$ at 700 . At inost, the Washington decision reserved for a future time the question whether a trial judge in an appropriate case could consider a nonstatutory mitigating circumstance. Neither the Washington decision nor any of the other decisions cited by the Songer court approved the practice of considering nonstatutory mitigating factors.

196. The court stated in Cooper that the statute slowed a legislative intent to create an exclusive list of the mitigating factors that could be einployed in determining the propriety of a death 
There is, therefore, no fair and substantial support for the Songer court's holding that the Florida courts had construed and applied the mitigating circumstances provision in a nonexclusive fashion in 19721978. Accordingly, the federal courts liave the power to review state law on this subject independently and, if the case law requires, to reject the Songer court's conclusion. We now venture an independent review of the 1972 statute, a review of the sort that a federal court could and should undertake to construe the ineaning and thus to determine the constitutionality of the pre-Songer statute.

ii. Independent review of the pre-Songer standard. The Florida statute provided that the jury and sentencing judge were to consider mitigating circuinstances "as enumerated in" the statutory list. ${ }^{197}$ This language reflects an intent to restrict mitigatory factors to those that are actually enuinerated in the statutory roster. ${ }^{198}$ The legislative history shows that the Florida legislature, presumably aiming to satisfy the requireinents of Furman as it understood them, specifically intended to enact a statute that would eliminate sentencer arbitrariness by requiring the sentencer to consider only those aggravating and mitigating circumstances that were explicitly designated in the statute. ${ }^{199}$ Moreover, as we have already shown, the Florida courts interpreted and applied

sentence, and that the courts "are not free to expand the list." 336 So. 2 d at 1139 \& n.7. The court further declared that evidence concerning matters other than the "itemized" mitigating and aggravating factors has no place in the capital sentencing hearing. Id. at 1139.

In its subsequent decision in Songer v. State, the Florida Supreme Court attempted to distinguish Cooper by declaring that "in Cooper, this Court was concerned not with whether enumerated factors were being raised as mitigation, but with whether the evidence offered was probative." Songer v. State, 365 So. $2 \mathrm{~d}$ at 700 . As one commentator has pointed out, the Songer court disingenuously misrepresented the Cooper decision in order to find some basis for distinguishimg it. Dix, supra note 74, at 137-38. The defendant in Cooper attempted to present evidence of his prior employment to demonstrate his ability to be rehabilitated but the court excluded this evidence on the ground that it failed to support one of the statutorily enumerated mitigating circumstances, and not on the ground that it was insufficiently probative. Id. at 138; Cooper v. State, 336 So. $2 \mathrm{~d}$ at 1139.

197. Fla. Stat. ANN. $\S \S 921.141(2)(b),(3)(b)$ (West Supp. 1979).

198. This was the statutory language that led the Florida Supreme Court in Cooper v. State to conclude that the legislature intended to restrict mitigating circumstances to the factors expressly identified in the statute. See note 177 and accompanying text supra. Similarly, the Colorado Supreme Court concluded that statutory language authorizing presentation of the mitigating circumstances "set forth in" the statutory roster must be interpreted as restricting mitigating circumstances to the statutorily enumerated factors. People v. District Court (Lohr), 196 Colo. 401, 406, 586 P.2d 31, 34-35 (1978), cert. denied, 440 U.S. 924 (1979).

199. In March 1972, just before the Supreme Court announced the Furman decision, the Florida legislature enacted a new capital sentencing statute that permitted consideration of mitigating circumstances "including but not limited to" the list of factors enumerated in the statute. 1972 Fla. Laws ch. 72-724. The statute was to take effect on October 1, 1972. However, the Furman decision was issued in June 1972, and the Florida legislature immediately began consideration of a new death penalty bill designed to remedy the constitutional deficiencies identified in Furman. See Cooper v. State, 336 So. 2 d at 1139 \& n.7; State v. Dixon, 283 So. 2d 1, 13 (1973) (Ervin, J., 


\section{the mitigating circumstances provision as exclusive. ${ }^{200}$ Thus, both by}

dissenting). This bill was eventually enacted as the present Florida death penalty statute. See Fla. Stat. ANN. § 921.141 (West Supp. 1980).

In an apparent response to Furman's condemnation of undisciplined sentencer discretion, the new death penalty bill provided that both aggravating and mitigating circumstances "shall be limited to" rosters of enumerated factors. JOURNAL OF THE FLORIDA HouSE OF REPRESENTAtives, Special Session 1972, Noveinber 29, 1972, at 18 [hereinafter cited as House Journal]. The House's comment to the bill declared that "matters to be considered are limited only to those aggravating and initigating circumstances enumerated in subsections (3) and (4)." $Y d$. at 19. This bill passed the House on November 29, 1972. Id. at 23.

The Senate amended the bill by deleting the words "limited to" in the introductions to the rosters of both aggravating and mitigating circumstances, and by providing that as to both aggravating and mitigating circumstances, the court could consider "[a]ny other evidence the court deems relevant to sentence." JourNal of the Florida Senate, SpeCial Session 1972, Noveinber 30, 1972, at 25 [heremafter cited as SENATE JOURNAL]. The House expressly refused to concur with these amendments. HouSE JoURNAL, November 30, 1972, at 41-42. The Conference Committee then recommended that the Senate withdraw its amendments, and proposed a Conference Committee bill that followed the form of the original House bill in many rcspects, including the House's version of the mitigating circumstances provision. See SENATE Journal, December 1, 1972, at 37, 39-40; HouSE JourNal, December 1, 1972, at 48, 50-52. The Conference Committee version of the bill passed both houses, SENATE Journal, Deceinber 1, 1972, at 39-40; House JouRNAL, December 1, 1972, at 50-52, and the Governor signed it imto law. Thus, the bill that was enacted as the 1972 death penalty statute incorporated the House's original intention to restrict mitigating circumstances to the factors enumerated in the statutory list.

In reaching the conclusion that the legislature intended to create an open-ended roster of mitigating circumstances, the Florida Supreme Court in Songer pointed to the lack of parallelisin in the prefaces to the statutory lists of aggravating and mitigating circumstances in the version of the statute that was enacted. While the list of aggravating circumstances provides that "[a]ggravating circumstances shall be limited to" the factors in the list, the statutory roster of mitigating circumstances merely provides that "mitigating circumstances shall be" the factors in the roster. FLA. STAT. ANN. $\$ \$ 921.141(5),(6)$ (West Snpp. 1980). This lack of parallelisin led both the Florida Supreme Court in Songer and the United States Suprene Court in Proffit v. Florida to assume that the roster of mitigating circumstances, unlike that of aggravating circumstances, was nonexclusive. Proffitt v. Florida, 428 U.S. at 250 n.8; Songer v. State, 365 So. $2 \mathrm{~d}$ at 700 \& n.l; see note 183 and accompanying text supra. The legislative history reveals, however, that this lack of parallelism is actually due to a technical oversight in the transcription of the Senate amendments in the bill. The SENATE JOURNAL reveals that the Senate voted to delete the words "limited to" with respect to both aggravating and mitigating circumstances, so that the bill would read: "Aggravating circumstances shall be [limited to] the following: . . .," and "Mitigating circumstances shall be [limited to] the following: . . ." Senate Journal, Noveniber 30, 1972, at 25. However, this parallelism was not transcribed into the bill transmitted to the House later that day. That text, as reported in the HouSE JOURNAL, erroneously read as follows: "Aggravating circumstances shall be limited to the following: ...," and "Mitigating circumstances shall be [limited to] the following: . . . HOUSE JouRNAL, November 30, 1972, at 41. The Conference Committee, restoring the House's version to a draft that adopted the Senate's provisions on many other issues, apparently failed to correct the error that had crept into the transcription of the bill. As a result, the 1972 death penalty statute was enacted with nonparallel langnage providing that "[a]ggravating circumstances shall be limited to the following" and "[n] itigating circumstances shall be the following." FLA. STAT. ANN. $\$$ 921.141(5), (6) (West Supp. 1980).

Thus, the legislative history slows clearly that the state legislature intended to restrict mitigating circumstances to the statutorily enumerated factors. The lack of parallel structure relied on by the Songer and Proffit courts to reach the opposite conclusion was due not to the legislature's desire to limit consideration of only aggravating and not mitigating factors, but rather to a smiple transcription error.

200. See notes 168-70, 175-77, 79 and accompanying text supra. 
legislative intent and by judicial construction, the 1972-1978 Florida statutory standard limited mitigating circumstances to the seven factors enumerated in the statute.

iii. The constitutionality of the pre-Songer standard. Once the true nature of the pre-Songer capital sentencing scheine is clear, it is readily apparent that the scheme violated Lockett, for it possessed precisely the same vice that resulted in the invalidation of the Ohio statute in Lockett. Like the Ohio statute, the pre-Songer standard limited mitigatimg circumstances to those listed in the statute. The sentencing authority could hear all the mitigating evidence that the defendant wished to present, but the statute required it to consider only the seven statutorily enumerated mitigating circumstances in determining sentence. As the Lockett Court observed with respect to the Ohio statute, ${ }^{201}$ the preSonger standard did not allow a nonstatutory factor to independently affect the capital sentencing determination. ${ }^{202}$ Thus, the pre-Songer Florida standard must fall along with the Ohio law.

iv. Summary. This section has demonstrated that a state court cannot use its statutory construction powers to evade the effect of Lockett. The problein of state court evasion is hardly unique to Florida, for other state supreine courts have similarly re-construed statutes to eliminate Lockett deficiencies and have then applied the new constructions retroactively to defeat the Lockett claims of defendants sentenced pursuant to the prior unconstitutional standards. ${ }^{203}$ In assessing the va-

201. Lockett v. Ohio, 438 U.S. at $604,607-08$.

202. The similarities between the pre-Songer standard and the Ohio law struck down in Lockett go beyond the exclusivity of the statutory rosters of mitigating circumstances. Under the Florida Supreme Court's construction of the statute, if the sentencer found one aggravating circumstance and no mitigating circumstances, then death was the required-and not discretionary-penalty. State v. Dixon, 283 So. 2d 1, 9 (Fla. 1973); see Elledge v. State, 346 So. 2d 998, 1002-03 (Fla. 1977). Thus, the pre-Songer standard operated in precisely the same inanner as the Ohio law, which also required the imposition of a death sentence if the sentencer found one or more aggravating circumstances and no statutory mitigating circumstances. See Lockett v. Ohio, 438 U.S. at 593-94.

203. The Alabama, Mississippi, and Nebraska statutes all employ the same language as the Florida law and provide that: "Mitigating circumstances shall be the following [enumerated factors in the statutory roster]." ALA. CODE \& 13-11-3 (1975); Miss. CODE ANN. \& 99-19-101 (Supp. 1979); NEB. Rev. STAT. $\$ \$ 29-2521,29-2523$ (1975). Prior to Lockett, the courts in each state appeared to apply the mitigating circumstances provision as exclusive. Jacobs v. State, 361 So. $2 d$ 640, 648 (Ala.), cert. denied, 439 U.S. 1122 (1978). (Tobbert, C.J., concurring and dissenting) ("The list of mitigating circumstances in section 13-11-7, Code of Alabama 1975, is exclusive, and the grounds argued by the petitioner do not fit within any of the seven enumerated factors in that section."); Evans v. State, 361 So. 2d 654, 663-65 (Ala. Crim. App. 1977), aff'd in part, rev'd and remanded in part, 361 So. 2d 666 (Ala. 1978), cert. denied, 440 U.S. 930 (1979) (sentencing judge considered mitigating circumstances "as described im" statutory roster); Coleman v. State, 378 So. 2d 640, 646 (Miss. 1979) (trial judge's instructions set out only statutory unitigating circumstances); Washington v. State, 361 So. 2d 61, 64 (Miss.), cert. denied, 441 U.S. 916 (1978) (jury instructions 
lidity of the Lockett claims of sucli defendants, a reviewing federal court sliould follow the same approach that we have used to test the constitutionality of the pre-Songer Florida sentencing scheme: The court should first examine wliether the state court construction lacks fair or substantial support in state law; if so, the reviewing court should identify the true nature of the standard under which the defendant was sentenced, and then determine the constitutionahity of that standard.

\section{Procedural Consequences of Invalidating a Statute on Lockett Grounds: The Implications for a Defendant Sentenced to Death Under the Statute}

When a deatli penalty statute is invalidated on Lockett grounds, the death sentences imposed pursuant to the statute must be reversed ${ }^{204}$ and the defendants resentenced. ${ }^{205}$ As we will show, resentencing must occur in all cases, whether or not the defendant attempted to gain sentencer consideration of a nonstatutory mitigating circumstance in his sentencing hearing. In those cases in which the defendant did try to obtain and was precluded from obtaming sentencer consideration of nonstatutory mitigating circumstances, the prejudice is self-evident. ${ }^{206}$ In those cases in whicli the defendant failed to present evidence of nonstatutory mitigating circumstances, it is impossible to determine whether that failure was due to the absence of nonstatutory circum-

referred solely to statutory mitigating circumstances); State v. Simants, $197 \mathrm{Neb} .549,562,567-69$, 250 N.W.2d 881, 889, 892-93, cert. denied, 434 U.S. 878 (1977) (considering exclusively statutory mitigating circumstances and commenting that "the Florida statute is very similar to the Nebraska statute in that the sentencing authority is required to weigh statutory aggravating and mitigating circumstances"); State v. Rust, 197 Neb. 528, 542-43, 250 N.W.2d 867, 876, cert. denied, 434 U.S. 912 (1977) (considering solely statutory mitigating circumstances in determining sentence).

Then, after Lockett was decided and defendants raised Lockett challenges to these statutes, the state supreme court in each state construed its respective statute as nonexclusive and rejected the Lockett claim on the ground that the statute had always been applied as nonexclusive. Jacobs v. State, 361 So. 2d at 652-53; Washington v. State, 361 So. 2d at 67-68; State v. Holtan, 287 N.W.2d 671, 674 (Neb. 1980).

Of course, a state supreme court is entitled to apply a new coustruction of a statute prospectively even though the construction is incousistent with the language of the statute and prior case law construing it. $C$. Bouie v. City of Columbia, 378 U.S. 347, 362 (1964) (retroactive application of new construction of criminal statute violated due process). See also Shuttlesworth v. Birmingham, 382 U.S. 87, 91-92 (1965). However, in each of these states, as in Florida, the state supreme court apphed the new construction retroactively to a defendant sentenced before the announcement of the new construction, on the rationale that the statutory language was clearly nonexclusive and had always been applied in such a maimer.

204. See, e.g., Bell v. Ohio, 438 U.S. at 642-43; Lockett v. Ohio, 438 U.S. at 608-09.

205. See, e.g. , State v. Kaiser, 56 Ohio St. 2d 29, 34, 381 N.E.2d 633, 636 (1978) (resentencing defendant who was originally sentenced to death under the statute struck down in Lockett).

206. The prime example of such a case is Lockett itself. Sandra Lockett atteinpted to receive, but was preveuted from receiving sentencer consideration of nonstatutory mitigating circumstances. See notes 32-39 and accompanying text supra. The Supreme Court reversed Lockett's death sentence and remanded for reseutencing. 438 U.S. at 608-09. 
stances in the case, a strategic decision on the part of defense counsel, or defense counsel's correct perception that the statute restricted mitigating circumstances to those enumerated in the statute. A defense attorney's decision not to present available evidence of nonstatutory mitigating circumstances-or not to pursue investigation seeking to discover such evidence-obviously would have been affected by a statutory proscription of consideration of such evidence by the sentencer. ${ }^{207}$ Therefore, doctrines of waiver and failure to object cannot be apphed to foreclose the defendant's Lockett challenge to the statute. ${ }^{208}$

The most complex and widely litigated aspect of resentencing following invalidation of a death penalty statute involves the question of whether the defendant can be resentenced to death pursuant to a subsequently enacted valid capital punishment statute. The majority of courts that have addressed this issue have concluded that a death penalty statute cannot be applied retroactively in such circumstances and that the maximum permissible penalty on resentencing is life imprisonment. ${ }^{209}$ This conclusion has been based on several different rationales. Some courts have held that the retroactive application of a subse-

207. See Evans v. Britton, 628 F.2d 400 (5th Cir. 1980) (defense failure to present evidence that would reduce the offense charged to a lesser included offense does not deprive the defendant of the benefit of Beck v. Alabama, 100 S. Ct. 2382 (1980), since defense strategy in the handling of any case would have been molded by the unconstitutional statutory proscription of consideration of lesser imcluded offenses).

208. See, e.g., State v. Evans, 120 Ariz. 158, 162, 584 P.2d 1149, 1153 (1978) (upon invalidation of the Arizona statute on Lockett grounds, defendant was remanded for resentencing even though he did not attempt to present any mitigating circumstances at his sentencing hearing, because reviewing court must assume that "he was relying on the limitations on mitigating factors imposed by [the statute]"). See also Cook v. State, 369 So. 2d 1251, 1257 (Ala. 1978) (irrevocability of death sentence necessitates that rcviewing court take special precautions to ensure that capital defendant was not prejudiced by an error even though he failed to object to the error); Commonwealth v. McKenna, $476 \mathrm{~Pa} .428$, 437-41, 383 A.2d 174, 179-81 (1978) (waiver doctrine will not be applied in capital cases; "[b]ecause unposition of the death penalty is irrevocable in its finality, it is unperative that the standards by which that sentence is fixed be constitutionally beyond reproach"). A reviewing court also cannot examine a rccord and conclude that there are no possible nonstatutory mitigating circumstances in the case and therefore that the inability to gain sentencer consideration of nonstatutory factors was harmless error. There are a "host" of "intangible" nritigating factors that could be present in any case, People v. District Court (Lohr), 196 Colo. 401, 407, 586 P.2d 31, 35 (1978), and the restrictive statute may well have been the cause of defense counsel's failure to attempt to introduce these intangible factors into the record. See Evans v. Britton, 628 F.2d 400, 401 (5th Cir. 1980).

209. People v. Harvey, 76 Cal. App. 3d 441, 447-49, 142 Cal. Rptr. 887, 890-92 (2d Dist. 1978); People v. Payne, 75 Cal. App. 3d 601, 606-08, 142 Cal. Rptr. 320, 323-25 (1st Dist. 1977); State v. Lindquist, 99 Ida. 766, 770-71, 589 P.2d 101, 105-06 (1979); People v. Hill, 78 11l. 2d 465, 474-76, 401 N.E.2d 517, 522 (1980); Bond v. State, 403 N.E.2d 812, 815-16 (Ind. 1980); Meller v. State, 94 Nev. 408, $409-10$ \& n.3, 581 P.2d 3, 4 \& n.3 (1978); State v. Rodgers, 270 S.C. 285, 292-93, 242 S.E.2d 215, 217-19 (1978); see People v. Teron, 23 Cal. 3d 103, 115-19, 588 P.2d 773, 779-82, 151 Cal. Rptr. 633, 640-42 (1979); Hudson v. Commonwealth, 597 S.W.2d 610, 610-11 (Ky. 1980); State v. Collins, 370 So. 2d 533, 534-35 (La. 1979); Miller v. State, 584 S.W.2d 758, 759-62 (Tenn. 1979) (state constitutional grounds). 
quently established death penalty standard to defendants tried and sentenced under the former law violates constitutional prohibitions against ex post facto legislation. ${ }^{210}$ Other courts have found that since the maximum punishment that could have been imposed constitutionally under the former statute was life imprisonment, double jeopardy precludes resentencing to the harsher punishment of death after the defendants have already begun serving their sentences. ${ }^{211}$ Still other courts have reached this result on common law rather than constitutional grounds, finding that canons of statutory construction preclude retroactive application of new death penalty legislation, at least in the absence of some express legislative nuandate for retroactive operation of the statute. ${ }^{212}$ And finally, some courts simply have declared that the maximum permissible punishment on resentencing is life imprisonment without articulating the basis for this holding. ${ }^{213}$

Some courts have, however, taken a contrary view and held that a subsequently established death penalty standard can be applied fully in the resentencing hearing and, if appropriate under the new standard, the defendant can be resentenced to death. ${ }^{214}$ The central issue in the conflict between the lower courts in this area is the proper interpretation of the Supreme Court's decision in Dobbert $v$. Florida. ${ }^{215}$ The Court held in Dobbert that ex post facto guarantees were not violated where a defendant was tried and sentenced under a new deatl penalty statute that had been enacted after the commission of his offense but before his trial for that offense. The lower courts that have permitted resentencing to death following invalidation of a death penalty statute have simply assumed that Dobbert applies to a defendant tried and sentenced under the old, unconstitutional standard. ${ }^{216}$ However, the

210. State v. Lindquist, 99 Ida. 766, 770-71, 589 P.2d 101, 105-06 (1979) (federal and state constitutional grounds); Miller v. State, 584 S.W.2d 758, 759-62 (Tenn. 1979) (solely on state constitutional grounds); see State v. Rodgers, 270 S.C. 285, 292-93, 242 S.E.2d 215, 217-19 (1978).

211. People v. Harvey, 76 Cal. App. 3d 441, 447-49, 142 Cal. Rptr. 887, 890-92 (2d Dist. 1978); People v. Payne, 75 Cal. App. 3d 601, 606-08, 142 Cal. Rptr. 320, 323-25 (1st Dist. 1977).

212. State v. Lindquist, 99 Ida. 766, 770-71, 589 P.2d 101, 105-06 (1979); People v. Hill, 78 Ill. $2 d$ 465, 474-76, 401 N.E.2d 517, 522 (1980); State v. Rodgers, 270 S.C. 285, 292-93, 242 S.E. 2 d 215, 217-19 (1978). This holding also emerges from a series of cases decided in the context of the first capital sentencing hearing rather than a resentencing hearing. See People v. Teron, $23 \mathrm{Cal}$. 3d 103, 115-19, 588 P.2d 773, 779-82, 151 Cal. Rptr. 633, 640-42 (1979); Hudson v. Commonwealth, 597 S.W.2d 610, 610-11 (Ky. 1980); State v. Collins, 370 So. 2d 533, 534-35 (La. 1979).

213. Bond v. State, 403 N.E.2d 812, 815-16 (Ind. 1980); Meller v. State, 94 Nev. 408, 409-10 \& n.3, 581 P.2d 3, 4 \& n.3 (1978).

214. State v. Watson, 120 Ariz. 441, 445, 453-54, 586 P.2d 1253, 1257, 1265-66 (1978), cert. denied, 440 U.S. 924 (1979); Upshaw v. State, 350 So. 2d 1358, 1361 (Miss. 1977); State v. Coleman, 605 P.2d 1000, 1010-15, 1056-57 (Mont. 1979), cert. denied, 100 S. Ct. 2952 (1980).

215. 432 U.S. 282 (1977).

216. See State v. Watson, 120 Ariz. 441, 453-54, 586 P.2d 1253, 1265-66 (1978), cert. denied, 440 U.S. 924 (1979); Upshaw v. State, 350 So. 2d 1358, 1361 (Miss. 1977); State v. Coleinan, 605 P.2d 1000, 1011, 1056-57 (Mont. 1979), cert. denied, 100 S. Ct. 2952 (1980). 
majority of lower courts-which have barred such resentencing to death-have found a constitutionally significant distinction between defendants like Ernest Dobbert, who from the beginning were tried and sentenced under the new, valid death penalty standard, and defendants who initially were tried and sentenced under the old, unconstitutional standard. ${ }^{217}$ Indeed, the Dobbert Court itself recognized a difference between defendants initially tried under a new standard and those whose "cases had progressed sufficiently far in the legal process as to be governed solely by the old statute, with the concomitant unconstitutionality of its death penalty provision."218

Thus, although the issue is far from settled, the bulk of the lower court case law and the better-reasoned constitutional and common law analysis support the conclusion that when a statute is invalidated on Lockett grounds, defendants tried and sentenced under the former, unconstitutional standard cannot be resentenced to death and can receive a maximum pumishment of life imprisonment.

\section{B. Constitutionality of Statutes as Applied: Lockett Requirements for an Individual Sentencing Hearing}

In addition to establishing basic requirements that a state death penalty statute must meet, the Lockett decision also affects the procedures employed in an individual sentencing hearing in a state with a constitutionally valid statute. The requirements for a sentencing hearing are founded on the Lockett primciples already identified as necessary to the constitutionality of death penalty statutes: the ability of the defendant to proffer all aspects of character, record, and offense; the power of the sentencer to consider all proffered aspects; and the use of those procedural devices necessary to enable the sentencer to actually consider each of the proffered factors. However, when applied to the trial court's practical tasks in conducting an individual sentencing hearing, these primciples take on soinewhat different form.

217. People v. Harvey, 76 Cal. App. 2d 441, 446-47, 142 Cal. Rptr. 887, 890 (2d Dist. 1978); State v. Rodgers, 270 S.C. 285, 292-93, 242 S.E.2d 215, $217-18$ (1978); Meller v. State, 94 Nev. 408 , 409-10 \& n.3, 581 P.2d 3, 4 n.3 (1978). This distinction has significance both for ex post facto and double jeopardy analysis. In Dobbert, the application of the new standard in the trial and sentencing learing did not result in the type of "detrimental" retroactive application of laws condemned by ex post facto guarantees. In contrast, the retroactive application of a new standard to a defendant tried and sentenced under the old, invalid standard would certainly impose "detriment" in that it would make it possible for the defendant to be executed, whereas previously execution could not occur. And where a defendant was tried and sentenced under the old statute and is now undergoing resentencing under the new standard, the defendant can invoke double jeopardy protections that were not applicable in the stage of the proceedings considered in Dobbert. People v. Harvey, 76 Cal. App. 2d at 446-47, 142 Cal. Rptr. at 890.

218. 432 U.S. at 301. 


\section{Admissibility of Defendant's Mitigating Evidence}

In the course of a typical hearing, the defense attorney seeks to present mitigating evidence to the sentencing judge or jury, and the judge inust determine the admissibility of any evidence whose introduction has been challenged by the prosecution. Because Lockett gives the defendant a right to proffer all mitigating circumstances, the trial court nust allow the defense attorney to present evidence of any aspect of character, record, or offense that the attorney wishes to proffer as a mitigating circumstance or as support for the existence of a mitigating circumstance. ${ }^{219}$ The Lockett decision, however, left open a central question concerning the admission of defense evidence of mitigating circuinstances: whether mitigating evidence can be excluded on the ground that it fails to coinply with local rules of evidence. A partial response came in Green v. Georgia, ${ }^{220}$ in which the Court held that the due process clause bars trial judges from rigidly applying local evidentiary rules im determining the admissibility of mitigating evidence. ${ }^{221}$ The judge in the Green case had applied the local hearsay rule to exclude mitigating evidence of the defendant's minor participation in a felony-murder committed by his co-defendant. ${ }^{222}$ The Court vacated the petitioner's sentence, holding that the "mechanistic" application of Georgia's hearsay rule in Green's capital sentencing hearing served to "defeat the ends of justice," ${ }^{223}$ and thus violated due process. ${ }^{224}$ The Court discerned substantial reasons for assuming the reliability of the excluded testimony and, citing Lockett, emphasized that the "excluded testimony was highly relevant to a critical issue in the punishment phase of the trial." 225

The Green holding logically apphes to all local rules of evidence

219. See People v. District Court (Lohr), 196 Colo. 401, 405-06, 586 P.2d 31, 33-34 (1978); Cobb v. State, 244 Ga. 344, 358-59, 260 S.E.2d 60, 70-71 (1979).

220. 442 U.S. 95 (1979) (per curiam).

221. The due process guarantees of the fifth and fourteenth amendments regulate the procedures employed in a capital sentencing hearing just as they regulate the procedures employed in a guilt trial. See note 148 supra.

222. 442 U.S. at 96.

223. Id. at 97 (quoting Chambers v. Mississippi, 410 U.S. 284, 302 (1973)). In Chambers, the defense had sought to introduce an out-of-court statement in which the declarant apparently announced that he, and not the defendant, had committed the killing at issue. The state trial judge barred the evidence since the state hearsay rule did not contain an exception for declarations against penal (as opposed to pecuniary) interest. 410 U.S. at 299. Moreover, the state's "voucher" rule, which prohibited parties from impeaching their own witnesses, barred Chambers froin calling the declarant to the stand and introducing his out-of-court statement against him. Id. at 29596. The Supreme Court held that local rules of evidence cannot be apphied "mechanistically" when such rules would threaten the "fairness and rehability [of] . . . the ascertainment of guilt and innocence" and thereby "defeat the ends of justice." Id. at 302.

224. 442 U.S. at 97.

225. Id. 
and not just the hearsay rule. ${ }^{226}$ The most significant implications of the decision, however, concern the application of local rules of relevancy. In Lockett, the Court noted that "[n]otlimg in this opimion limits the traditional authority of a court to exclude, as irrelevant, evidence not bearing on the defendant's character, prior record, or the circumstances of his offense."227 Thus, the Lockett right to present mitigating evidence is limited to evidence that is relevant to character, record, or offense. However, the Court did not imdicate whether the appropriate standard of relevancy im determining the admissibility of particular evidence is the local relevancy rule or a uniform general standard that may be more consistent with the spirit of the Lockett requirement that the sentencer be able to hear and consider all factors that might call for a less severe penalty than death. The Green decision resolves this issue and demonstrates that local relevancy requirements cannot be applied rigidly to exclude mitigating evidence. In considering whether a picce of evidence offered in mitigation of a death sentence is relevant, the courts should weigh the potentially mitigating influence of the evidence agamst the harm that could result from the violation of the relevancy rule, and should resolve all doubts in favor of admittimg the evidence. ${ }^{228}$

\section{Jury Instructions}

The Lockett decision also affects the trial judge's imstructions to the sentencing jury. As the discussion of the Georgia statute has demonstrated, the imstructions must mention specifically the proffered mitigatimg factors to ensure that the sentencer can consider those factors in determining sentence. The Georgia statute and jury instructions violated Lockett by precluding specific mention of any proffered miti-

226. See Collier v. State, 244 Ga. 553, 567, 261 S.E.2d 364, 375-76 (1979), cert. denied, 100 S. Ct. 1346 (1980).

227. 438 U.S. at 604 n.12.

228. In Collier v. State, $244 \mathrm{Ga}$ at 567, 261 S.E.2d at 376 (1979), cert. denied, 100 S. Ct. 1346 (1980), the Georgia Supreme Court endorsed such a procedure, and stated that "the Constitution requires that evidence which would be inadnissible under an evidentiary rule must not automatically be excluded if tendered in a capital case in mitigation of punishment." Id. However, in a questionable application of this rule to the facts of the case, the Collier court upheld the trial court's exclusion of character evidence offered in mitigation of a sentence of death.

As a general inatter, the Green principle will affect only the evidentiary rulings in an mdividual hearing and will not affect state statutes. However, a unique example of a statute that violates Green is the Florida law as construed in Songer $v$. State and applied from the time of the Songer decision in December 1978 until the enactment of the amendinents to the Florida statute in June 1979. See notes 180-84 and accompanying text supra. The Florida Supreme Court in Songer indicated that its construction of the Florida statute permits a trial judge to exclude as "insuffciently probative" evidence of a defendant's prior einployment, even though that evidence might tend to establish a potential for rehabilitation. By specifically authorizing such stringent application of evidentiary rules in determining the admissibility of mitigating evidence, the Florida statute as construed in Songer violates the due process principles set out in Green. 
gating factors in the instructions. The jury instructions used in inany other states suffer froin the related constitutional deficiency of mentioning only the applicable statutory mitigating circumstances and not any proffered nonstatutory factors. ${ }^{229}$ As one lower court has held, Lockett requires specific reference to both statutory and nonstatutory mitigating factors to avoid detracting froin the weight of the nonstatutory factors. ${ }^{230}$

In addition to itemizing proffered mitigating factors in the jury instructions, the judge should instruct the jury that factors can mitigate the defendant's sentence by demonstrating that a death sentence would not serve the ends of retribution and deterrence. Our examination of the Texas statute revealed that a particular aspect of the defendant's character, record, or offense can have mitigating weight either by persuading the jury that leniency is appropriate or by disproving the retributive or deterrent value of a death sentence in the particular case. Thus, a factor such as minor participation in a killing committed by another can mitigate by demonstrating that the ultimate retribution of death is not appropriate or that the defendant's offense is not a crime likely to be deterred. However, a lay juror may not understand that a factor can mitigate by disproving the retributive or deterrent value of a death sentence. Thus, in order to ensure that a sentencer may fully consider evidence offered to disprove the retributive or deterrent value of a death sentence, the judge should mstruct the jury on this aspect of mitigation. And since most lay jurors will be imacquainted with the concepts of retribution and deterrence, the judge's instructions should include definitions of these terms.

\section{IV}

Beyond Lockett: The Right to Present Evidence CONCERNING THE RETRIBUTIVE AND DETERRENT CAPACITIES OF THE

Death Penalty as a Factual Predicate for the Judgment ON Mitigating CiRcumstances

In the 1976 Cases, the plurality established the capital defendant's right to present mitigating circumstances, and indicated that the sentencer's judgment on mitigating circumstances serves to ensure that an individual death sentence is consistent with the goals of retribution or deterrence and therefore is in accord with the dignity of man. ${ }^{231}$ In

229. See, eg., Washington v. State, 361 So. 2d 61, 64-65 (Miss.), cert. denied, 441 U.S. 916 (1978); State v. Brown, 607 P.2d 261, 282 (Utah 1980) (Maughan, J., concurring and dissenting) (quoting the jury instructions in the sentencing hearing).

230. State v. Johnson, 298 N.C. 47, 72-74, 257 S.E.2d 597, 616-17 (1979).

231. See text accompanying notes 13-30, 91-100 supra. 
Lockett, the Court went one step further and held that the right to present and receive sentencer consideration of mitigating circuinstances extends to all aspects of character, record, and offense, and requires a sentencer to consider the independent mitigating weight of each aspect. In a number of recent cases, capital defendants have raised an issue that follows logically from these principles: whether a capital defendant has a constitutional right to present evidence directly relating to the retributive or deterrent capacities of the death penalty as a part of the argument that the death penalty is not appropriate in the particular case. ${ }^{232}$ Defeudants have, for example, offered the testimony of expert witnesses to show that the imposition of the death penalty in their case would not deter others from committing similar capital offenses, and have tried to present testimony concerning the precise nature of the penalties of death and life imprisonment to show that incarceration would be adequate retribution for the defendant's offense. ${ }^{233}$

In the cases in which this issue has been raised, the courts have rejected the defendants' evidence on retribution and deterrence as irrelevant. ${ }^{234}$ These courts have explained that Lockett deals exclusively with mitigatimg circumstances of the individual defendant's character, record, and offense, and does not confer the right to present other types of mitigatory evidence. ${ }^{235}$ The courts are certainly correct in their analysis of the specific holding in Lockett: The Lockett decision concerns only mitigating circumstances of character, record, and offense, and the Court explicitly stated that it did not intend its decision to limit the authority of the trial judge to exclude evidence that is not relevant to these factors. ${ }^{236}$ The reasoning of the Lockett opimion, however, extends beyond the holding in the case. The imposition of the death penalty has been justified by reference to the legitimate retributive and deterrent goals that the penalty may serve. A defendant's eighth

232. See, e.g., State v. Cherry, 298 N.C. 86, 97-98, 257 S.E.2d 551, 559 (1979), cert. denied, 100 S. Ct. 2165 (1980); Dix, supra note 74, at 154-55 (describing Franklin v. State, No. 57,348 (Tex. Crim. App. May 24, 1978), rev'd on other grounds, No. 57,348 (Tex. Crim. App. Oct. 24, 1979) (on rehearing)). Such evidence has also been proffered in several capital sentencing hearings in Illinois. Letter from Robert P. Isaacson, Assistant Public Defender, Cook County, Illinois, to Randy Hertz (March 20, 1980) [hereinafter cited as Isaacson Letter] (on file with the California Law Review).

233. Evidence of this type was proffered in the Illinois capital sentencing hearings. Isaccson Letter, supra note 232. Similar types of evidence were proffered in State v. Cherry, 298 N.C. 86, 97, 257 S.E.2d 551, 559 (1979), cert. denied, 100 S. Ct. 2165 (1980).

234. See, e.g., State v. Cherry, 298 N.C. at 98,257 S.E.2d at 559; Dix, supra note 74 , at 154 . In the lllinois sentencing hearings, only one out of dozens of proffered witnesses has been permitted to testify on matters of this type. Isaacson Letter, supra note 232.

235. State v. Cherry, 298 N.C. at $98-99,257$ S.E.2d at $559-60$.

236. See Lockett v. Ohio, 438 U.S. at 604 n.12 ("nothing in this opinion limits the traditional authority of a court to exclude as irrelevant, evidence not bearing on the defendant's character, prior record, or the circumstances of his offense"). 
amendment right to present evidence that disproves the existence of these justifying factors in his own case is the logical extension of the principles established in the 1976 Cases and in Lockett .

A factor offered by the defendant can mitigate by convincing the jury that the retributive and deterrent purposes that alone can justify the imposition of the death penalty will not be furthered by imposing a death sentence in the particular case. ${ }^{237}$ In addition, if the jurors are to comprehend mitigating circuinstances in this context, they inust be instructed on the meaning of retribution and deterrence, and on the relevance of these factors to their role as sentencer. ${ }^{238}$ If these difficult judgments are to be anything more than visceral hunches about what constitutes an appropriate retributive or deterrent punishunent in an individual case, far more than a mere imstruction may be needed. In order to make its judgment intelligently, the jury will in many cases require a factual predicate of inforination relevant to retribution and deterrence, a predicate that might imclude inforination not directly relevant to character, record, or offense.

The retributive judgment is a determination of the degree of punishunent and suffering that is appropriate for or proportionate to the moral culpability of the offender and his offense. ${ }^{239}$ Thus, when a capital defendant introduces mitigating evidence of his relatively minor record and the existence of circumstances that he believed to liave created a moral justification for his actions, the sentencing jury must consider whether these factors render him sufficiently less culpable than other nurder defendants that the ultimate sanction of deatl is not appropriate. However, there are no absolute criteria for gauging the degree of culpability or moral imquity of an individual criminal

237. See text accompanying notes 91-100 supra.

238. See text accompanying notes $138-40$ supra.

239. Gibbs, The Death Penalty, Retribution and Penal Policy, 69 J. CRIM. L. \& CRIMINology 291, 293-96 (1978); see H.L.A. HART, Punishment ANd REsponsibility 25 (1968); A. VoN Hirsch, Doing Justice: The Choice of Punishments 66-94 (1976). The Supreme Court's analysis of the retributive foundations of capital punishmeut incorporates two different inodels of retributiou: (1) the pure retribution or revenge principle, which assumes the categorical moral justice and necessity of punishment as the "just deserts" for a criminal action; and (2) the instrumental concept of retribution that justifies institutional revenge as necessary to ensure that citizens will not take the law into their own hands and personally satisfy their desire for vengeance. See Gregg v. Georgia, 428 U.S. at 183-84; The Supreme Court, 1975 Term, 90 HARv. L. REv. at 65-66 \& n.25. For further discussion of these models of retribution, see H. PACKER, supra note 109, at 37; Radim, supra note 23, at $1047 \& \mathrm{n} .221,1049-50,1054-56$. The concept of punishment proportiouate to the moral culpability of the offeuder and offense satisfies both the categorical and instrumental goals of retributiou. By adjusting the degree of punishment to the extent of culpability of the individual, the criminal justice system succeeds in giving the offender his "just deserts." See H.L.A. HART, supra, at 25. And, in imposing the degree of retribution that is proportionate to the individual's offense, the criminal jnstice system provides sufficient "justice" to satisfy the public's need for vengeance and avoid vigilante action. See E. VAN DEN HAAG, PUnishing Criminals 12-13 (1975). 
offender. ${ }^{240}$ The defendant's culpability can be assessed only by comparing his character and the precise circumstances of his offense with other capital offenders and offenses. ${ }^{241}$ Thus, in order to gauge fully the extent to which a defendant's relatively minor record and purported moral justification render him less culpable, the sentencer must have some knowledge of the criminal records of other capital offenders and the circumstances of other capital offenses. ${ }^{242}$

Similarly, both of the possible punishments that the sentencer could impose-death and life imprisonment-mvolve extreme hardship and thus could serve as retribution for the commission of murder. ${ }^{243}$ In order to use mitigating evidence of character, record, and offense to make the difficult judgment as to which of these two punishments is appropriate, the sentencer necessarily must have some knowledge of the nature of the punishments. In the noncapital context, sentencing judges routmely consider the actual conditions that exist in prisons and the physical and psychological burdens of imprisonment in determining the degree of imprisonment that is appropriate to the defendant's offense. ${ }^{244}$ Indeed, as penologists have pointed out, a retributive calculation of the degree of pain and suffering involved in a particular sentence of imprisonment must take into account the harsh and often brutal conditions of prison life. ${ }^{245}$ Thus, in order to use the proffered mitigating evidence to determine whether life imprisonment

240. Gibbs, supra note 239, at 295-96; see Commonwealth v. O'Neal, 369 Mass. 242, 261, 339 N.E.2d 676, 686-87 (1975) (Tauro, C.J., concurring); W. KAufMANN, WrTHour GulLT AND JUSTICE 64, 71 (1973).

241. Advocates of the retributive model of criminal justice rarely discuss the mechanics of administering retribution in individual cases. Gibbs, supra note 239, at 295. The retributivists who have addressed this issue have recognized that the retribution imposed in a particular case must reflect the degree to which the offender and his offense are nore or less culpable than other offenders and offenses. See, eg., A. Von HIRSCH, supra note 239, at 74, 79, 82; Hospers, Retribution: The Ethics of Punishment, in Assessing the Criminal: Restitution, Retribution, and tHe LeGal Process 181, 188-90 (R. Barnett \& J. Hagel eds. 1977). Similarly, in appellate review of the appropriateness and proportionality of a death sentence in a particular case, the impossibility of setting objective criteria for determining culpability has resulted in a procedure of comparing the individual capital offender with other offenders and offenses to determine the appropriateness of the death sentence. Dix, supra note 74, at 107.

242. Cf. State v. Williams, 205 Neb. 56, 一, 287 N.W.2d 18, $31-36$ (1979) (Krivosha, C.J., concurring and dissenting) (explaining that capital sentences should be imposed in the most heinous cases in order to achieve the goal of retribution, and then determining the heinousness of the particular defendant's offense by comparing the case with other capital cases).

243. In its discussion of retribution, the plurality in the 1976 Cases simply focused on the retributive value of the punishment of death. See Gregg v. Georgia, 428 U.S. at 183-84. However, the 1976 decisions implicitly recognized that life imprisonment can be an appropriate degree of retribution for homicide offenses. H. BEDAU, supra note 29, at 117-18.

244. Buchner, Scale of Sentence Severity, 70 J. Crum. L. \& Cruminology 182, 187 (1979) (reporting the results of an empirical study of sentencing that included interviews with trial judges).

245. See, e.g., A. Von Hirsch, supra note 239, at 115. 
is adequate retribution for the defendant's offense, the capital sentencing authority must have some knowledge of the actual conditions that exist in prison facilities. ${ }^{246}$ Similarly, in gauging the retributive value of a death sentence, the sentencing jury should be aware not only of the self-evident consequence of the extinction of the defendant's life, ${ }^{247}$ but also the acute physical and psychological suffering that attends the infliction of the death penalty. ${ }^{248}$ This infornation is relevant in deciding whether to impose the death penalty, and should not, as is now the practice, be kept froin the sentencing authority.

In order to apply proffered mitigating evidence to the question of whether execution of the particular defendant will deter commission of similar offenses by similar offenders, the sentencer also inay require

246. In addition to the information concerning the brutality and larshness of prison life, evidence of prison conditions would logically include information about the programs available inside the various institutions and the rights and duties of inmates. The most pertinent information would be the prospects of parole for a capital defendant who lias been sentenced to life imprisonment. However, as several courts lave concluded, information concerning the likelihood of parole must be excluded from a capital sentencing hearing because of the great danger that a jury, confronted with the prospect of the defendant back out on the streets in a certain number of years, will impose a death sentence for the impermissible reason of guarding agamst this occurrence. See, e.g., People v. Morse, 60 Cal. 2d 631, 644, 388 P.2d 33, 41, 36 Cal. Rptr. 201, 209 (1964); Commonwealth v. Aljoe, 420 Pa. 198, 207-09, 216 A.2d 50, 55-56 (1966).

247. In some capital cases, defendants have sought to introduce testimony by clergy concerning the moral, religious, and ethical ramifications of execution. Isaacson Letter, supra note 232. Although all jurors, of course, lrave a personal understanding of the concept of death, evidence of this type is necessary to lelp thein to appreciate the unique aspects of death by state-ordered execution.

248. All traditional forms of execution presently employed in this country-hanging, firing squad, electrocution, and lethal gas-involve severe plysical pain and suffering. Gardner, Executions and Indignities-An Eighth Amendment Assessment of Methods of Inflicting Capital Punishment, 39 OHIo ST. L.J. 96, 119-28 (1978). In recent years, a growing nuniber of states lrave begun to employ intravenous injection of a lethal drug as the inethod of execution. IDAHO CODE $\$ 19-$ 2716 (1979); N.M. STaT. ANN. § 31-14-14 (Supp. 1980); OKLA. STAT. ANN. tit. 22, § 1014 (West 1980); Tex. Code Crim. Proc. AnN. art. 43.14 (Vernon 1979). The lethal injection is painless if administered properly. Gardner, supra, at 129. However, if the drug is injected improperly (intramuscularly rather than into the veim), the prisoner will suffer inuscular contractions and considerable plysical pain. Id. Improper administration of the drug is extreinely likely since physicians are precluded by their Hippocratic Oath from participating either directly or indirectly in the administration of this killing drug. See American Psychiatric Association, Position Statement on Medical Participation in Capital Punishment, 137 AMER. J. Psychiatry 11 (1980); Malone, Death Row and the Medical Model, HASTINGs CENTER REPort, October 1979, at 5.

All forms of execution involve the probability of psychological suffering. See Gardner, supra, at 119-28; Malone, supra, at 6. In fact, the lethal injection inay be the least humane in terms of psycliological cruelty, since the prisoner can awaken froin the preliminary barbituate and realize that lie is slowing suffocating to death as a result of the injection. Malone, supra, at 6 .

Moreover, the months and often years spent waiting for execution subject the inmates of death row to extreme psycloological pressures. Furman v. Georgia, 408 U.S. 238, 287-88 (1972) (Brennan, J., concurring); District Attorney v. Watson, 411 N.E.2d 1274, 28 CRIM. L. REP. 2169, 2170 (Mass. 1980); Gallemore \& Parton, Inmate Responses to Lengthy Death Row Confinement, in Capital Punishment In the United States 527 (H. Bedau ed. 1976); Johnson, Under Sentence of Death: The Psychology of Death Row Confinement, 5 LAW \& PsYcHOLOGY REv. 141 (1979). 
factual information not directly related to the defendant's character, record, or offense. The crux of this deterrence judgment is the assessment of the deterrent effect of the type of offense that the defendant has committed. ${ }^{249}$ Even more than the retributive judgment, this may be a factual matter. For example, the plurality in the 1976 Cases explained that, as a matter of simple logic, capital punishment inight not deter murders that are not carefully and rationally planned. ${ }^{250}$ Thus, evidence that the defendant committed the inurder in a inonient of passion can mitigate by slowing that the defendant did not rationally plan the murder and therefore probably could not have been deterred fron doing so. Althougl the correlation between calculated action and deterrent effect may be self-evident to those who are well acquainted with the criminal justice system, it is unlikely that lay jurors will perceive this relationship unless they are told of it. Accordingly, in order to give effect to the mitigating weight of evidence of the influence of passion in an offense, the sentencing jurors must learn the preliminary facts concerning the improbability of deterring noncalculated offenses. ${ }^{251}$

The critical principle that enrerges fron this discussion of retribution and deterrence is that the capital sentencing authority simply cannot consider and give effect to evidence that mitigates by disproving the retributive or deterrent value of a deatli sentence unless it is made aware of the additional information that forms the factual predicate for the retributive and deterrent judgments. The reasoning in Lockett, when extended to its logical conclusion, indicates that a capital defendant has an eightl aniendment right to present these preliminary facts. The Lockett decision requires states to einploy sentencing procedures that will guard against the "risk that the deatli penalty will be imposed in spite of factors which may call for a less severe penalty."252 The absence in a particular case of a retributive or deterrent purpose for imposimg a death sentence is just such a factor. The admission of the preliminary facts concerning retribution and deterrence, therefore, is

249. See notes 114-15 and accompanying text supra.

250. Gregg v. Georgia, 428 U.S. at 185.

251. The need for such preliminary facts is even inore acute in cases involving offenses such as murder for hire, where logic cannot supply an answer to the question of whether the crime can be deterred. The plurality in the 1976 Cases suggested, without any empirical evidence, that the coldly calculating hired assassin is the prime example of an individual who can be deterred by capital punishment. Gregg v. Georgia, 428 U.S. at 186. Yet an equally logical argument can be made that a hired assassin is less likely to be deterred by the threat of a death sentence, since he will assume, with good reason, that he can escape detection. Zeisel, supra note 29, at 338-39. In cases involving offenses of this kind, the deterrent value of imposing the death penalty can be assessed most accurately by considering empirical data concerning the likelihood of deterring the specific type of offense. A jury cannot be expected to make an intelligent assessment of mitigating evidencc proffered to demonstrate the absence of deterrent value in imposing the death sentcnce in a particular case without the benefit of such empirical data.

252. 438 U.S. at 605. 
necessary to ensure that the sentencer can consider factors that disprove the retributive or deterrent value of a death sentence. Accordingly, the logic of the Lockett decision indicates that the Lockett right to present and to receive independent sentencer consideration of mitigating circumstances should be extended to encornpass a right to present evidence on the retributional and deterrent capacities of capital punishment.

This extension of Lockett would have hittle effect on the constitutionahity of most state statutes on their face. Most statutes provide for the defendant's presentation of "any mitigating evidence relevant to sentence," and therefore permit the introduction of preliminary facts of this type. ${ }^{253}$ Extending Lockett to recognize a right to present such facts, however, would profoundly affect the apphication of these statutory standards in particular capital sentencing hearings. As noted earher, ${ }^{254}$ several trial judges have excluded background inforination concerning retribution and deterrence as irrelevant. Although these trial judges correctly decided that such evidence was not relevant to the character, record, or offense of the defendant, they erred in excluding the evidence, since it is crucial to an inforined assessment of other proffered mitigatory evidence of character, record, and offense. For this reason, the capital defendant has an eighth amendinent right to present the information.

\section{$\mathrm{V}$ \\ CONCLUSION: LOCKETT AND SENTENCER Discretion}

Examination of the Lockett decision has shown that Lockett substantially expanded the capital defendant's right to present mitigating circumstances. Under Lockett, the defendant is entitled to present all mitigating evidence relevant to his character and record and to the circumstances of his offense. The defendant also has the right to a sentencer that can give independent mitigating weight to all proffered circumstances of character, record, and offense.

In their separate opmions in Lockett, Justices White and Rehnquist expressed conceru that the discretion that the decision grants the

253. See, e.g., State v. White, 395 A.2d 1082, 1087-88 (Del. 1978) (discussing DeL. CodE ANN. tit. 11, § 4209 (1979)); State v. McCormick, 397 N.E.2d 276, 278-79 (Ind. 1979) (discussing 1ND. CodE ANN. § 35-50-2-9(c) (1978)); State v. Holtan, 205 Neb. 314, —, 287 N.W.2d 671, 674 (1980) (construing Neb. Rev. STAT. \$ 29-2523 (1979)). As the Supreine Court has pointed out, all three of the statutes sustained in the 1976 decisions permitted defense presentation of "any mitigating evidence." Lockett v. Ohio, 438 U.S. at 606-07. However, subsequent to the 1976 decisious, the Florida legislature amended its statute, and the Florida law is now among the minority of state statutes that unconstitutionally preclude defense presentation of preliminary facts concerning retribution and deterrence. See 1979 Fla. Sess. Law Serv. ch. 79-353.

254. See notes 234-35 and accompanying text supra. 
sentencer to consider mitigating circuinstances is too great, and constitutes a return to the unguided discretion condemned in Furman v. Georgia..$^{255}$

The response to this objection is that Lockett is entirely consistent with Furman and the 1976 Cases, because it grants broad sentencer discretion only on the mitigating and not on the aggravating side of the sentencing equation. The Furman requirement of guided discretion was based on the need to purge arbitrariness and caprice from the capital sentencing decision ${ }^{256}$ and to establish a "ineaningful basis for distinguishing the few cases in which . . . [the death penalty] is imposed from the many cases in which it is not."257 Explaining the holding in Furman, the plurality in the 1976 Cases stated that the severity and finahity of the death penalty gives rise to a correspondingly great need for rehiability in the decision to impose death. ${ }^{258}$ Thus, Furman was based on the saine eighth amendment requirement of reliability in capital sentencing that was the core of the Lockett holding.

The 1976 Cases provide the key to understanding low the eiglith anendment reliability principle can be manifested in the very different requirements of Furman and Lockett. In Gregg v. Georgia, the defendant raised an eighth amendment challenge to the unguided discretion inherent in the prosecutor's autliority to plea bargain away the possibility of a death sentence, the jury's ability to convict a defendant of a lesser mcluded noncapital offense, and the Governor's and parole board's powers of commutation. ${ }^{259}$ Rejecting this claim, the Gregg plurality explaimed:

The existence of these discretionary stages is not determinative of the issues before us. At each of these stages an actor in the criminal

255. Lockett v. Ohio, 438 U.S. at $622-23$ (White, J., concurring and dissenting); id. at 629,631 (Rehnquist, J., concurring and dissenting). The Texas Court of Criminal Appeals implicitly raised this same concern in Adams v. State, 577 S.W.2d 717 (Tex. Crim. App. 1979), rev'd on other grounds, 100 S. Ct. 2521 (1980). In upholding the Texas statute against a Lockett cliallenge, the Adams court asserted that the defendant's broad reading of Lockett would return to the jury the unbridled discretion proscribed in Furman by enabling the jury to evade the purportedly objective criteria in the Texas sentencing scheme and decide the propriety of execution according to "its own lights." 577 S.W.2d at 729. As the examination of the Texas statute has demonstrated, the Adams court erred in rejecting the defendant's broad reading of Lockett and his challenge to the Texas statute. See Part II A supra. Under Lockett, the jury can indeed rely on "its own lights" in making the decision whether the defendant deserves to die. The Adams decision therefore implicitly poses the question raised by Justices White and Rehnquist: whether sucl broad sentencer discretion is consistent with the Furman mandate of objective standards for guiding sentencer discretion in capital sentencing.

256. See note 7 and accoinpanying text supra.

257. Furman v. Georgia, 408 U.S. at 313 (White, J., concurring) (quoted as part of the core of the Furman decision in Gregg v. Georgia, 428 U.S. at 188).

258. See Woodson v. North Carolina, 428 U.S. at 302-05; Gregg v. Georgia, 428 U.S. at 18889.

259. 428 U.S. at 199. 
justice system makes a decision which may remove a defendant from consideration as a candidate for the death penalty. Furman, in contrast, dealt with the decision to impose a death sentence on a specific individual who had been convicted of a capital offense. Nothing in any of our cases suggests that the decision to afford an individual defendant mercy violates the Constitution. Furman held only that, in order to minimize the risk that the death penalty would be imposed on a capriciously selected group of offenders, the decision to impose it had to be guided by standards so that the sentencing authority would focus on the particularized circumstances of the crime and the defendant. ${ }^{260}$

Thus, there is a central distinction for eighth ainendment purposes between the decision to impose a death sentence and the decision to afford mercy. The 1976 Cases deinonstrated that the standards for ensuring a reliable decision to impose deatlı must include botll careful regulation of the circuinstances that can be used to aggravate sentence and provisions for the sentencer's consideration of the reasons against imposition of a death sentence. ${ }^{261}$ Lockett refined these requirements by specifying that the mandate of reliability im imposing the death sentence ${ }^{262}$ requires that the sentencer be allowed to consider any and all aspects of cliaracter, record, and offense tliat mitigate agamst death.

The Gregg decision essentially holds that the state cannot execute a defendant unless it estabhshes, according to constitutionally sufficient criteria of aggravation and constitutionally mandated procedures, that capital pumshment is appropriate for that defendant. Nothmg in Gregg, however, requires the state to execute defendants for whom such a findimg is made. The sentencing authority can find that mitigatmg circumstances established by defense evidence outweigh such aggravating factors. It can also imvoke whatever standards it wisliesobjective or otlierwise-to nullify the significance of any state proof of aggravation. ${ }^{263}$

Justices White and Rehnquist are certainly correct in stating that the Lockett decision grants the sentencer unfettered discretion in deciding whether to afford mercy. ${ }^{264}$ However, as the above-quoted passage froin Gregg demonstrates, the eighth amendment reliability principle does not require guided discretion in the decision to afford mercy to an mdividual defendant. Indeed, the Georgia statute, approved in Gregg as satisfying the Furman mandate of guided discretion in the decision

260. Id.

261. See notes $24-30$ and accompanying text supra.

262. 438 U.S. at 605.

263. A jury in a guilt trial similarly acts as the "conscience of the community" in deciding whether to soften the application of the law by convicting the defendant of a lesser charge or even nullify the law by acquitting him against the evidence. Westen \& Drubel, Towards a General Theory of Double Jeopardy, 1978 SUP. CT. REv. 81, 130.

264. See note 255 and accompanying text supra. 
to impose death, represents the epitome of unguided discretion in the decision to afford mercy: The statute allows the jury to make a binding recommendation of mercy even though the jury did not find any mitigating circumstances in the case. ${ }^{265}$

The difference between the requirements governing the decision to impose death and those governing the decision to afford inercy perhaps can be best understood by considering the central mechanism for ensuring rehability in the decision to convict an individual of any capital or noncapital offense: the standard of proof beyond a reasonable doubt. As the Supreme Court has explamed, the standard of proof in a guilt proceeding is the rigorous criterion of beyond a reasonable doubt because of our society's judgment that an erroneous decision to convict is more opprobrious than an erroneous decision to acquit. ${ }^{266}$ In the capital sentencing proceeding, the comparative weight of the interests at stake is even more sharply pronounced. An erroneous decision to extinguish the defendant's life is far more opprobrious than an erroneous decision to spare the defendant and sentence him to life imprisonment. ${ }^{267}$ Accordingly, the eighth amendment requires reliability and guided discretion in the decision to impose death, but not in the decision to afford mercy by imposing a noncapital sentence.

Thus, Lockett is consistent with Furman and with the 1976 Death Penalty Cases. All of these decisions represent the Supreme Court's attempts to fulfill the eighth amendment mandate of reliability in the decision to impose a death sentence on a particular defendant.

265. See Gregg v. Georgia, 428 U.S. at 197. For further discussion of this provision of the Georgia statute, see note 122 and accompanying text supra.

266. In re Winship, 397 U.S. 358, 363-64 (1970); see Addington v. Texas, 441 U.S. 418, 423-24 (1979); $c f$. Ballew v. Georgia, 435 U.S. 223, 234 (1978) (explaining that one of the reasons for finding that reduction of the number of jurors below six violates the sixth and fourteenth amendments is that reduction of the jury panel impermissibly increases "the risk of convicting an innocent person" even though it decreases the "risk of not eonvicting a guilty person").

267. Woodson v. North Carolina, 428 U.S. at 305 ("the penalty of death is qualitatively different from a sentence of imprisonment, however long. Death, in its finality, differs more froin life imprisonment than a 100-year prison term differs froin one of only a year or two."); Reid v. Covert, 354 U.S. 1, 77 (1957) (Harlan, J., eoncurring) ("I do not concede that whatever process is 'due' an offender faced with a fine or a prison sentence necessarily satisfies the requirements of the Constitution in a capital case. The distinction is by no means novel . . nor is it negligible, being hiterally that between life and death."). 